
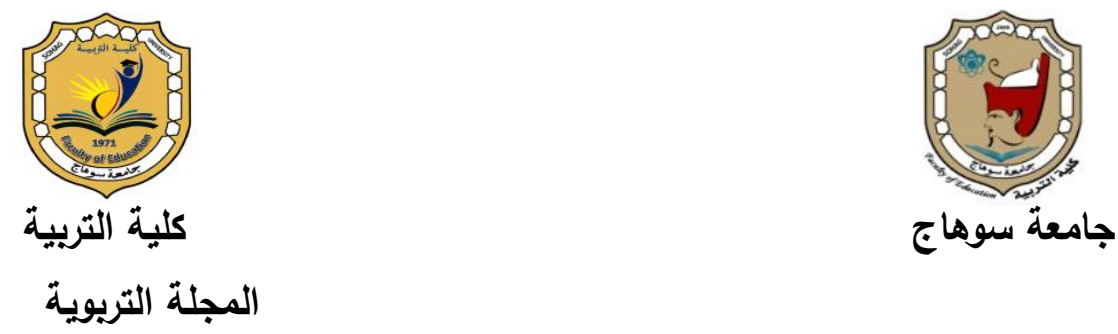

\title{
أداء الباحثين في إعداد هشروعاتهم البحثية بين الرشاقة والبدانة العلمية في ضوء البراديهم البحثي: دراسة نظرية
}

$$
\begin{aligned}
& \text { إعداد } \\
& \text { أ.د/ بشرى إسماعيل أحمد أرنوط } \\
& \text { أستاذ علم النفس الإششادي-كلية التربية } \\
& \text { جامعة الملك خالد - المملكة العربية السعودية } \\
& \text { كلية الآداب - جامعة الزقازيق- مصر }
\end{aligned}
$$

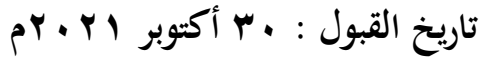

تاريخ الاستلام : • ب أكتوبر اY.Yم

DOI: 10.12816/EDUSOHAG.2021. 


\section{مستخلص البحث باللفة العربية:}

يعد البحث العلمي أحد أعمدة الاستثمار المحلي والعالمي، لهذا تسعى الدول للاهتمام بإعداد كوادر من الباحثين المؤهلين معرفيًا ومهاريًا، للتظلب على ما يواجه البحث العلمي في الوطن العريي من تحديات وصعويات، أدت إلى مخرجات لا تليق بتاريخ العرب وما حققوه من إسهامات بارزة في مجال البحث العلمي. تناول هذا البحث موضوع الرشاقة والبدانة في أداء الباحثين أثناء إعداد وتتفيذ وصياغة مشروعاتهم وأطروحاتهم البحثية. إذ أنه بمراجعة الأدبيات النظرية حول موضوع هذا البحث، لاحظت الباحثة وجود اهتمام بحثي منذ ثمانينيات القرن

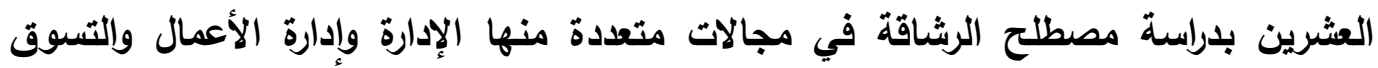
والإنتاج والتلوم البذنية والرياضية والهندسة وغيرها. في المقابل، يوجد نقص في الاهتمام

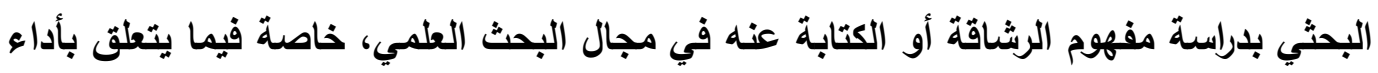
الباحثين في مشروعاتهم ومخطوطاتهم. لهذا، هدف هذا البحث إلى دراسة موضوع الرشاقة

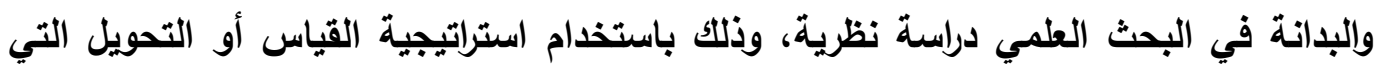

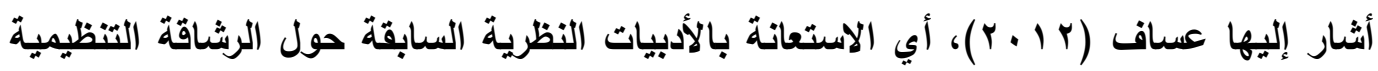

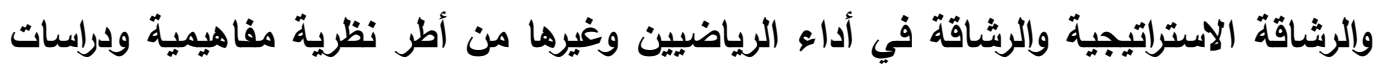
سابقة، وتحويلها لموضوع الرشاقة في مجال البحث العلمي. في ضوء ذلك، توصل البحث الحالي لصياغة إطار نظري حول مفهوم الرشاقة والبدانة البحثية في ضوء البراديجم البحثي،

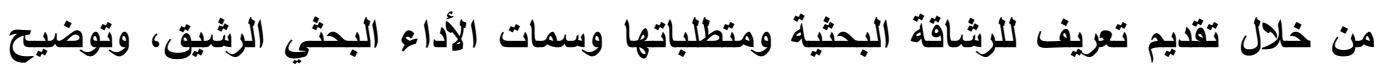
مفهوم البدانة البحثية وسمات الأداء البحثي البدين ومخاطره. كما سردت الباحثة خصائص الأطروحة البحثية الجيدة، وحددت أبرز الأخطاء الثائعة التي يقع فيها الباحثين عند إعدادهم لمشروعاتهم وأطروحاتهم، والتي تتسبب في بدانة أدائهم وترهل مشروعهم البحثي وفقدان الميزة التنافسية. في ضوء هذه الاستنتاجات، صاغت الباحثة عدة توصيات منها عقد دورات تدريبية عن الرشاقة والبدانة البحثية، وإعداد دليل إرشادي للباحثين حول أبرز الأخطاء الشائعة في إعداد المشروع أو المخطوطة التي تسبب بدانة أدائهم، وذلك ليُسهم هذا البحث بما توصل إليه من نتائج في نشر ثقافة رشاقة الأداء بين المشتفلين بالبحث العلمي في الجامعات والمراكز البحثية، ليمكنه من استغلال الفرص والمقدرات الجوهرية في انتاجهم البحثي وتحقيق الميزة 
التنافسية. كذلك لتبصيرهم بمخاطر البدانة البحثية وما تسببه من ضعف وترهل في إنتاجهم العلمي، مما يُعجزهم عن تحقيق الميزة التنافسية وتأخر تصنيف جامعاتهم عالميًا.

الكلمات المفتاحية: البحث العلمي-المشروع البحثي-الأطروحة البحثية- الرشاقة

البحثية- البدانة البحثية- الضمير الحي- البراديجم البحثي -

منهجية توقعات القارئ-الميزة التنافسية. 


\section{Researchers' Performance in Preparing their Research Projects Between Scientific Agility and Obesity in the Light of the Research Paradigm: A Theoretical Study}

\section{Prof. Boshra Ismael Ahmed Arnout}

Professor of Counseling Psychology

College of Education - King Khalid University - Kingdom of Saudi Arabia Faculty of Arts - Zagazig University - Egypt

\section{Abstract:}

Scientific research is one of the pillars of local and global investment, and that is why countries are seeking to prepare qualified researchers with knowledge and skills, to overcome the challenges and difficulties facing scientific research in the Arab world, which led to outputs that are not worthy of the history of the Arabs and their outstanding contributions in the field of scientific research. This research dealt with the issue of agility and obesity in the performance of researchers when preparing and formulating their research projects and theses. By reviewing the theoretical literature on this subject, the researcher noticed a research interest since the eighties of the twentieth century in studying the term of agility in various fields, including management, business administration, shopping, production, sports and physical sciences, engineering and others. On the other hand, there is a lack of research interest in studying or writing about the concept of agility in the field of scientific research, especially with regard to the performance of researchers in their projects and theses. Therefore, this research aimed to study agility and obesity in scientific research, a theoretical study, using the measurement or transformation strategy referred to by Assaf (2012). From the previous theoretical literature on organizational agility, strategic agility, agility in athlete performance and other conceptual theoretical frameworks and studies, the researcher precedent, and transformed it into agility in the field of scientific research. In light of this, the current research reached to formulate a theoretical framework about the concept of scientific agility and obesity according to the research paradigm, by providing a definition of research agility and its requirements and characteristics of agile research performance, and clarifying the concept of research obesity and its risks. The researcher also listed the characteristics of a good research thesis, and identified the most common mistakes that researchers fall into when preparing their projects and theses, and cause the obesity in their performance, sagging project and theses and loss of competitive advantage. In light of these findings, the researcher formulated several recommendations, including holding training courses on agility and research obesity, and preparing a guide for researchers about the most common mistakes in preparing the project and theses that cause their performance obesity, so that this research contributes to its findings in spreading the culture of agility 
performance to engaged in scientific research in universities and research centers that enable them to exploit the essential opportunities and capabilities in their research production to achieve competitive advantage, and enlighten them about the dangers of research obesity and the scientific weakness and slack in their scientific production, which prevents them from achieving competitive advantage and the delay of their universities in international rankings.

keywords: scientific research- research project-research thesis- research agility- research obesity-conscientiousness- research paradigmreader expectations methodology- competitive advantage. 


\section{مقلدمة البحثث :}

يعد البحث العلمي أحد الأنشطة الإنسانية التي تهدف إلى حل المشكلات التي تؤرق البشرية وتهددها، ولهذا يسعى كل بحث علمي لتحقيق أهداف عظيمة من وصف لمشكلات أو تفسير لظواهر أو ضبط وتحكم في المشكلات التي قد تظهر في المجتمع، والتنبؤ بما ستؤول إليه مستقبلاً ومحاولة التذخل لإصلاحها ومعالجتها. لذا يعتبر البحث العلمي وسيلة من وسائل التمية البشرية والمجتمعية المستدامة، ومن ثم يحتاج البحث العلمي إلى عدة إجراءات كي يكون بحثاً علميًا متكاملاً ورصينًا، فجودة كل خطوة من خطوات البحث تعتمد على جودة الخطوات الأخرى التي تسبقها، لذلك يحتاج الباحثين لتكوين قاعدة علمية معرفية رصينة بشأن ضوابط إجراءات البحث العلمي، ومعايير الصياغة الجيدة لكل جزء من مشروعهم أو أطروحتهم

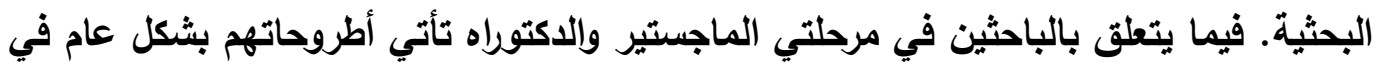

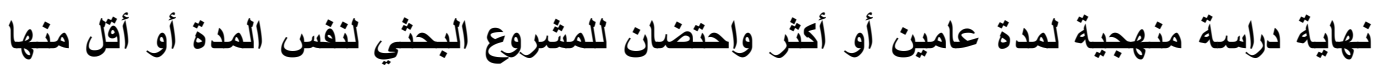
أو أطول، لذلك يتطلب إعداد مشروعاتهم أو مخطوطاتهم البحثية مستوى أكثر احترافًا لما له من لهن وزن كبير إذ أنه يحمل اسم الباحث؛ والباحث سيتحمل مسؤولية كل حرف فيه. لذلك من المهم أن يتجنب الباحث قر الإمكان ارتكاب أبي أخطاء ولو بسيطة؛ والتي من المحتمل أن تقلل من تأثير عمله البحثي، وتجعله عرضة للانتقادات من المشرف أو المناقش أو من قراء البحث وجمهوره، وتجعل عمله البحثي يتسم بالبدانة والترهل بدلاً من الرشاقة والاقتصادية. إن العالم اليوم يمر بتغيرات متلاحقة في كافة ميادين الحياة مما أثر على النشاط الإنساني في كافة مجالاته، والتي من بينها البحث العلمي. من ثم، فإن هذا النشاط الإنساني يحتاج إلى إنى

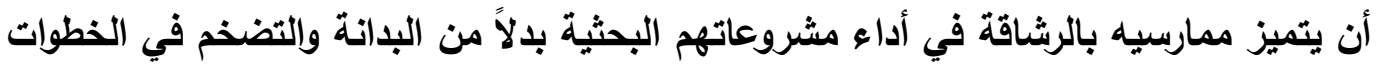
والإجراءات. ويالقياس لمعنى الرشاقة في علم الإدارة والعلوم الرياضية والهندسية، فإن الرشاقة في الأداء البحثي أحد المتطلبات الأساسية لإكمال المشروع البحثي وتنفيذ المهام المرتبطة به الإدهاته بأقل وقت وجها وأقل عدد من الأخطاء الشكلية والمنهجية، ومواجهة التحديات والتهايدات، واستغلال الفرص المتاحة واستثمار موارد الباحث وقدراته العقلية لتتحقى في العمل البحثي

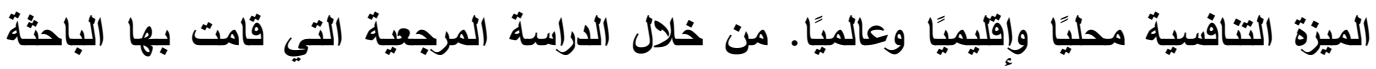
لمصطلح الرشاقة Agility في الأدبيات النظرية العربية والأجنبية في عدة تخصصات من أبرزها 
علم الإدارة وإدارة الأعمال والهندسة والتربية البلنية أو علوم الرياضة، فإن الرثاقة في البحث العلمي أو الرشاقة البحثية هي أحد أبعاد المؤسسة التعليمية، فالبحث العلمي أحد معايير

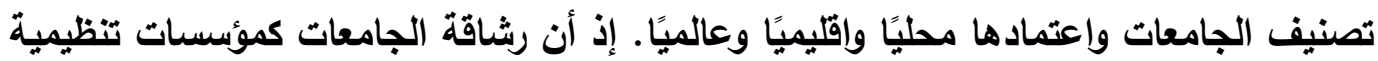
لن تتحقق إلا من خلال رشاقة أداء الباحثين الذين ينتمون إليها في أعمالهم البحثية وتحقيق واتيق الميزة التنافسية. لهذا نجد اهتمام كافة الجامعات بتطوير البحث العلمي وتذليل الصعويات والعقبات التي تواجه الباحثين وتخصيص الجوائز والبدلات والحوافز لتشجيع ذلك، ولتحقيق التميز المؤسسي ولتتبوأ الجامعات مراتب متقدمة في التصنيفات العالمية الدولية، لذلك تبنت الكثير من الجامعات العربية والأجنبية مبدأ الرشاقة التنظيمية تحقيقًا لروئتها ورسالتها وأهدافها. إذ تعد جودة البحث العلمي أحد متطلبات بقاء الجامعات والمراكز البحثية واستمرارها في ظل ما فرضته العولمة من تحديات ومنافسة قوية. جاء هذا البحث إيمانًا بأن البحث العلمي يهدف لحل المشكلات، ولأن أبرز مشكلات البحث العلمي تتمثل في ضعف مخرجاته بسبب ما يتسم به أداء بعض الباحثين في الدول العربية من التضخم والبدانة البحثية وترهل بحوثهم وأطروحاتهم المنشورة وشيوع قضايا الاستلال العلمي.

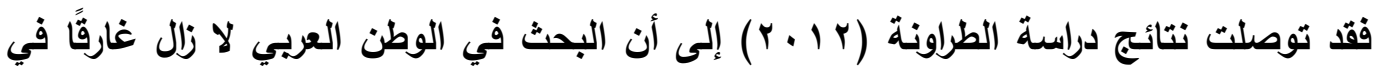

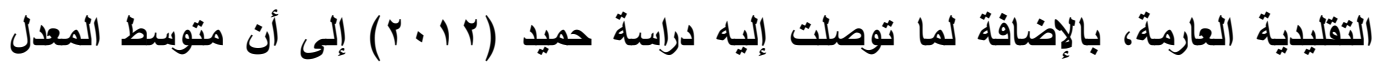

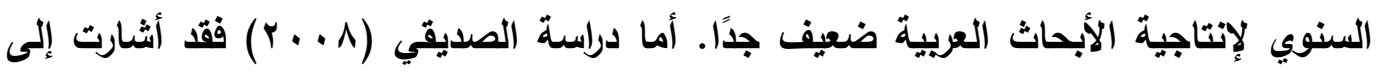
غياب استراتيجية لتأهيل البحث العلمي وفق المعايير الدولية. لذلك، يعد البحث الحالي محاولة

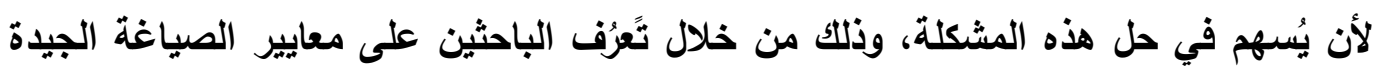
لمشروعاتهم ومخطوطاتهم البحثية في ضوء البراديجم البحثي الذي يقوم عليه تصميم

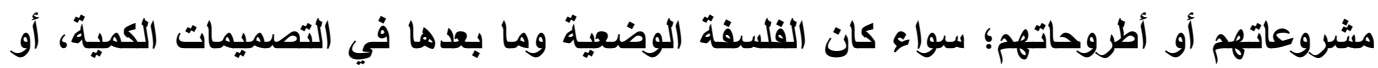
القلسفة البنائية التفسيرية الاجتماعية في التصميمات النوعية، أو الفلسفة البراجماتية في التصميمات المختلطة أو المزجية. أيضًا ليكتثف الباحثين الأخطاء الشكلية والمنهجية في أجزاء مشروعاتهم أو مخطوطاتهم البحثية، ويكتبوها في ضوء البراديجم البحثي ومنهجية توقعات القارئ، ولكي يُظهر الباحثين اتجاه إيجابي نحو إتقان صياغة مشروعاتهم وأطروحاتهم البحثية في كل أجزائها في ضوء معايير الصياغة الجيدة والنماذج المعتمدة من الجامعة أو المؤسسة المانحة، ويشعرون بالتالي بالمسؤولية تجاه مشروعهم البحثي واحترام قواعد وأخلاقيات البحث 
العلمي، ويتقبلون ما يوجه إليهم من انتقادات علمية رصينة بناءة ومن ثم يتحمسون لتجويد عملهم البحثي.

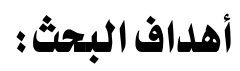

يهرف هذا البحث إلى تحقيق ما يلي: 1. تحديد معنى الرشاقة البحثية ومتطلباتها. r. وصف سمات الأداء البحثي البدين وعواقبه. r. تحديد مكونات وخصائص المخطوطة البحثية الجيدة. ـ. توضيح دور البراديجم البحثي في إعداد وصياغة المشروع البحثي. ه. التعرف على أبرز الأخطاء الشائعة في أداء الباحثين لمشروعاتهم البحثية.

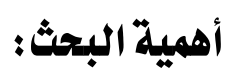

ا. تتجلى أهمية هذا البحث في حداثة موضوعه. إذ تناول بالدراسة رشاقة أداء الباحثين

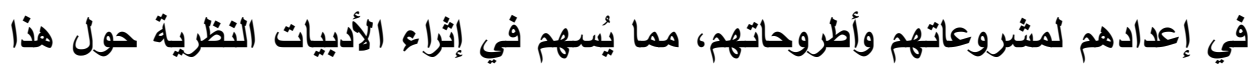
الموضوع الحيوي في ضوء جودة البحث العلمي وتصنيف الجامعات. r. فتح أفاق بحثية جليدة أمام الباحثين لاراسة موضوع رشاقة الأداء البحثي باستخدام التصميمات الكمية أو النوعية أو المزجية. r. توجيه انتباه الباحثين والمشرفين لأبرز الأخطاء التي قـ يقع فيها الباحثين أثناء إعدادهم لمشروعاتهم، ومن ثم الوعي بها والحذر والحيطة من الوقوع فيها.

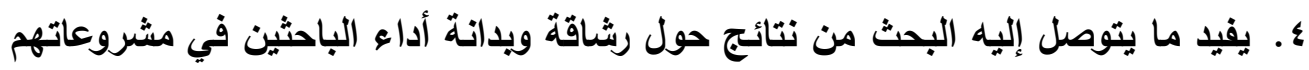
البحثية في التخطيط لتدريب الباحثين والمشرفين العلميين حول مفهوم الرشاقة والبدانة البحثية لتنمية التفكير في نتائج وعواقب كل منها. ه. تفيد نتائج هذا البحث المسؤولين في وكالات الدراسات العليا والبحث العلمي من إعداد

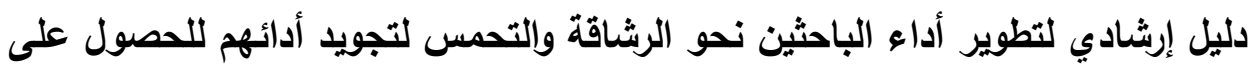
ميزة تنافسية محليًا وإقليميًا وعالميًا. 


\section{الخلثية النظرية للبحث:

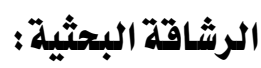

استخدم مصطلح الرشاقة Agility في العديد من السياقات في علم الإدارة والعلوم الرياضية والتسويق والإنتاج والهندسة وغيرها. وياستخدام الباحثة استراتيجية القياس والتحويل

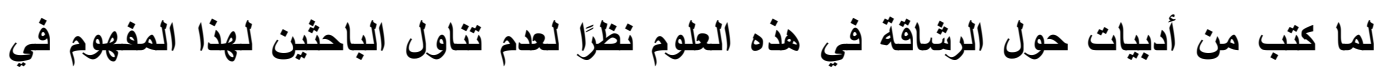
البحث العلمي رغم أهميته ولكون البحث العلمي أحد معايير تصنيف الجامعات كمؤسسة تنظيمية تطبق استراتيجية الرشاقة، فإن الرشاقة البحثية تثثير إلى رشاقة أداء البهاء الباحثين في

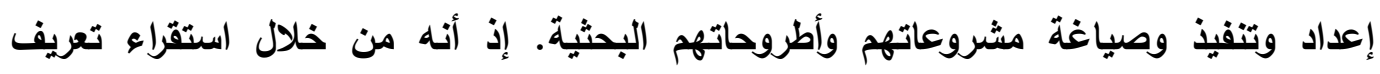
الرشاقة وُجد أنه يُقصد بها المرونة الفكرية والتوقع (Sheppard \& Young, 2007)، Goldman, Nagel \& Priess, 1995; Harris \& ) تقديم المنتج في الوقت المناسب Carapiet, 2006; Agarwal, Shankar\& Tiwari, 2007

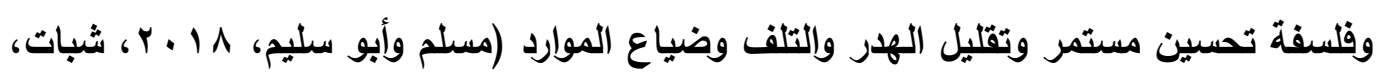
$\cdot(r \cdot r$.

عليه يمكن أن يُشتق من خلال أدبيات مفهوم الرشاقة في العلوم المختلفة التي اهتمت بدراسته، تعريف للرشاقة البحثية يثير إلى قدرة الباحث على تجاوز التحديات التي تواجهه في

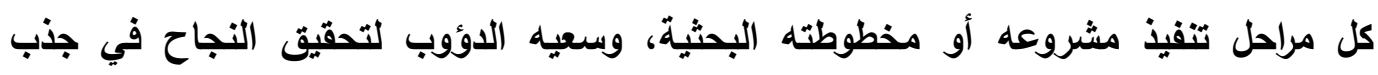
جمهور البحث من مشرف وأعضاء لجنة الدراسات العليا والقراء فيما بعد، وتقييم أدائه باستمرار، والتفكير في كيفية التعامل مع التغيرات والتحديات والصعويات أثناء تنفيذ المشروع

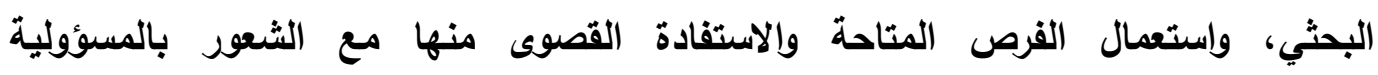
والاستقلالية والالتزام والانضباط مع المرونة وعدم التذمر أو التعجل في خطوات البحث منادئ وإجراع|ته التنفيذية.

إن الباحث الذي يتمتع أدائه بالمرونة البحثية يستطيع الاستجابة السريعة الواعية لملاحظات جمهور البحث من مرشد أكاديمي أو مشرف علمي وأعضاء لجنة السيمنار والدراسات العليا وغيرهم، مما يجعله يفكر استباقيًا بالفرص والتهديدات ولمصادر القوة والمقدرات الجوهرية ومن ثم يمتلك هذا الباحث القدرة على تكييف أداعه بما يتفق مع ضوابط البحث 
العلمي وإعداد مشروعه أو مخطوطته البحثية بدقة وإتقان، والتحكم فيما يواجهه من مشكلات وصعويات في ظل التقدم التقتي والمعرفي الهائل والتغيرات في منهجية البحث العلمي وفلسفته وظهور فلسفات ما بعد الحداثة كالتحويلية والبراجماتية. مما جعل هناك حاجة ماسة وضرورية إلى الرشاقة العلمية والفكرية لمواجهة هذه التحديات من خلال السعي الحثيث من جانب الباحث لخفض التكاليف في الوقت والجها والمال وزيادة سرعة الأداء وجودته وتقليل نسبة الهرر في الموارد الثخصية والبيئية المتاحة له، إذ أن نجاح الباحث مع هذه التطورات الجديدة في مجال العلم يحتاج إلى خصائص وقدرات في الباحث قد تختلف في طبيعتها عن تلك المطلوية في أي وقت مضى. الباحثين الآن ليسوا بحاجة إلى مهارات تكنولوجية وتقتية إضافية فحسب، بل بحاجة ماسة لأن يكونوا أكثر مرونة وانفتاحًا واستجابة للتغيرات السريعة في البيئة وما ينتج عنها من ظهور مشكلات وقضايا جديدة تحتاج إلى اهتمام بحثي، وينعكس ذلك بلا شك على أداء الباحث وإدارته لعمله البحثي من تخطيط وتتظيم وتنسيق وسيطرة على ما يطرأ من مشكلات أثناء تنفيذ مشروعه البحثي. إن الرشاقة البحثية تتطلب وجود مواصفات معينة يجب أن يتحلى بها أداء الباحث في مشروعه أو أطروحته لإرضاء جمهور البحث وقرائه ومعرفة توقعاتهم من جهة، ومن جهة ثانية الاستجابة السريعة لتوجيهاتهم ومقترحاتهم، والتجاوب مع التغيرات التي يطلبها مشرفه العلمي لإني واللجان المختصة. كما تتطلب الرشافة البحثية شفافية الباحث في عرض إجراءات بحثه وخطوات تنفيذها بما يحقق توفر معايير المصداقية والموثوقية فيما يصل إليه مشروعه البحثي من نتائج تُقتع جمهور بحثثه. لهذا، فإن الباحث الذي يتمتع بالتظيم الذاتي؛ يستطيع أن يوظف ما لايه من قدرات ومهارات في تعديد المهام المطلوية منه؛ ويشعر بقدرته على القيام بهذه المهام بكفاءة في ضوء مقدراته الجوهرية وموارده الشخصية وكذلك الموارد المتاحة له في البيئة من مصادر لهار

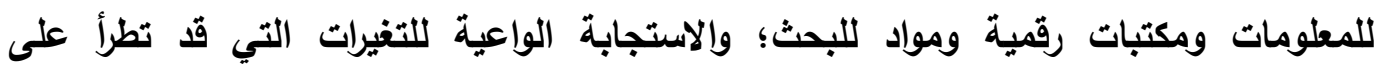
مشروعه البحثي؛ فضلاً عن سعيه المستمر للتعلم والتدريب لتطوير أداءه البحثي بما يحقق له الميزة التنافسية محليًا وأقليميًا وعالميًا. كما أن الباحث الذي يتسم بالضمير الحي Conscientiousness أي التظيم، المثابرة، الضبط الأتي، الكفاءة، المثابرة والإصرار، الدافعية والكفاح من أجل الإنجاز المتميز، التروي، 
الدقة والحذر قبل البدء في العمل، العمل الجاد والدؤوب دون كلل أو ملل، والفعل الصائب، العزيمة القوية رغم الانتقاد والتحمس للتصحيح، العمل بحب وأخلاق مستتيرًا بالقيم والأخلاقيات، الرغبة في إنجاز المشروع البحثي على أكمل وجه ويدقة مع الانتباه التام إلى أدق التفاصيل

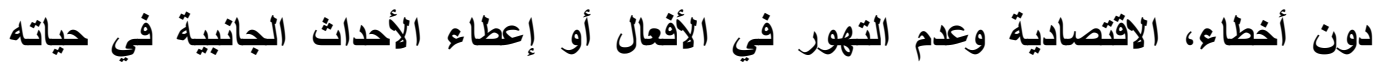

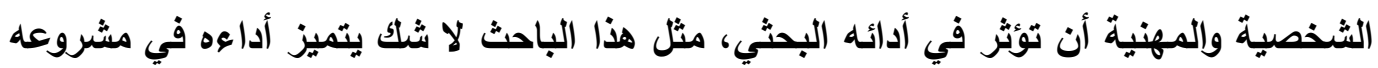

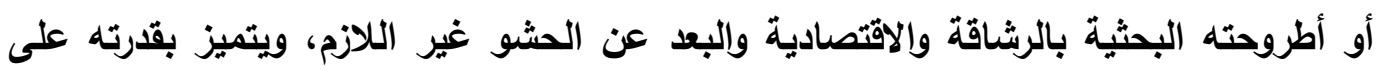
الكتابة الأكاديمية الحكيمة وإلضرورية. عليه، فإن الرشاقة في أداء الباحث، تعني قدرته على العمل المريح في بيئة تنافسية

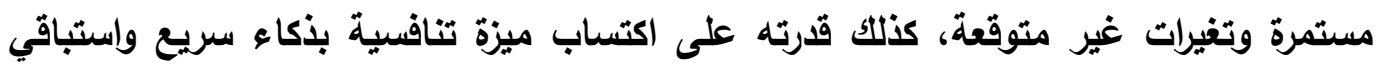

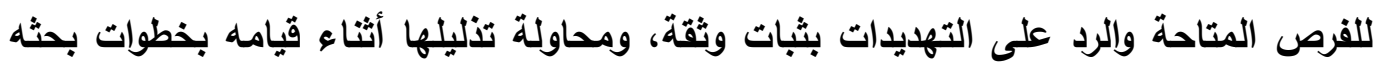

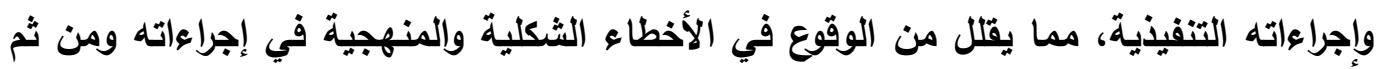

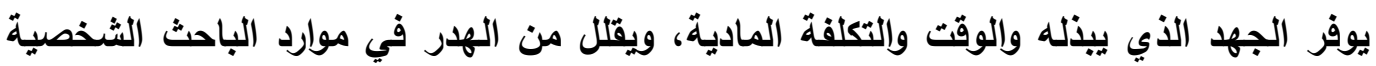
والبيئية، لهذا نجد أن رشاقة أداء الباحث في مشروعه أو مخطوطته البحثية ترتبط بما يمتلكه من مقدرات ذاتية وسمات شخصية كالتظيم الذاتي والمرونة والذكاء الاستباقي والضمير الحي.

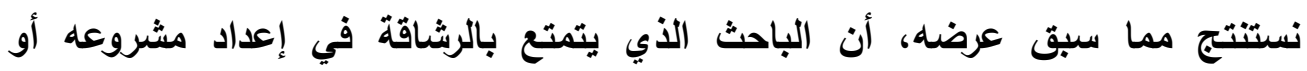

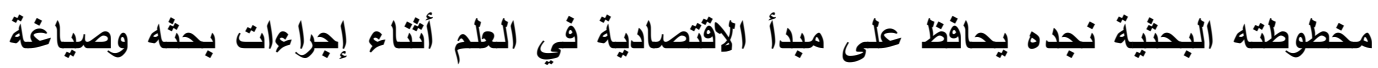
مشروعه أو مخطوطته، ويسير في الطريق الصحيح مع اليقظة العلمية والعقلية الدائمة والضمير الحي بما يجب عليه الالتزام به من قواعد ولوائح وأخلاقيات، ويما يدور حوله من الفئل أحداث وتغيرات، دون تعقيد أو إطالة منه. وياستخدام استراتيجية التحويل من الأدبيات النظرية السابقة حول منطلبات تحقيق الرشاقة

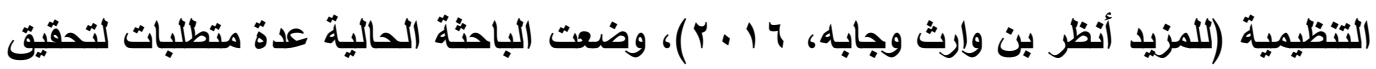
الرشاقة في الأداء البحثي، هي: ا. بذل جه متواز من الباحث لخطوات وإجراءات البحث العلمي بما يحقق النفع والفائدة. r. انجاز العمل البحثي المطلوب في الوقت المحدد بيقظة ووعي ودقة. 
r. التقييم والنقد الذاتي البناء من الباحث وتحمل المسؤولية الواضحة تجاه عمله، والتوقف عن استكمال إجراءات بحثه إذا اكتثف وجود خطأ ما فيها، وعدم استئناف العمل إلا بعد تصحيح الخطأ ومعالجته. ـ. تنظيم العمل البحثي، وتخلص الباحث من كل ما هو غير ضروري ولا حاجة له اثناء كتابة مشروعه أو أطروحته البحثية لضمان سلامة الأداء من جهة، ولإرضاء جمهور البحث وتحقيق توقعاتهم من جهة أخرى. ه. خلق جو من الطمأنينة النفسية والارتياح واللهدوء والاستقرار يتحقق من خلاله قدرة الباحث على إدارة عمله أو مشروعه البحثي بكفاءة ومهارة وإتغلال مقدراته الجوهرية والموارد البيئية المتاحة له. 7 ـ الانضباط في أداء الباحث بما يتماشى مع القوانين واللوائح والأنظمة، وتعليمات المشرف ولجنة الدراسات العليا واللجان المختصة والمناقشين. V. المحافظة على موارد الباحث وخاصة الوقت، ومن ثم إزالة الهـر بما يحقق إنجاز العمل البحثي في أقل وقت وجها وتكلفة وأقل أخطاء أو اختفائها تمامًا. ^. المرونة والتنظيم الذاتي واستغلال الفرص المتاحة والمقدرات الجوهرية لتحقيق الميزة التنافسية في البحث العلمي. 9 ـ الضمير الحي والكفاح من أجل إنجاز المشروع البحثي في الوقت المحدد له، والتفكير في النتائج والعواقب. • 1 ـ تحديد البراديجم البحثي أو الفلسفة والأفكار التي يتبناها الباحث حول العالم من حوله قبل البدء في المشروع البحثي أي أثناء التخطيط، والالتزام بها وينوع التصميم البحثي الأي اختاره وفقًا لهذه القلسفة في كافة إجراءات البحث وخطواته التنفيذية. 1 ا. مراعاة ما يتوقعه جمهور البحث وقراعه عند الثروع في كتابة المشروع أو الأطروحة البحثية، والاحتفاظ بأيديهم عند قراعاتهم للمشروع أو المخطوطة البحثية بلعًا من العنوان وحتى أخر سطر بالمشروع أو الأطروحة البحثية. 


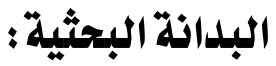

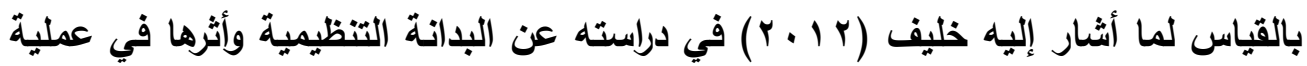
التصحر الوظيفي، إذ حدد عدة مؤشرات للبدانة التظيمية ومنها التضخم الوظيفي وانخفاض الإنتاجية وغيرها. فإن البانة لاى الباحث العلمي من وجهة نظر الباحثة الحالية تنطوي على البى

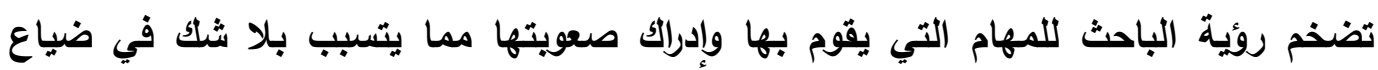
استفادته من الفرص المتاحة أمامه ومقدراته الجوهرية، وكثرة التهايدات الناتجة عن الأخطاء

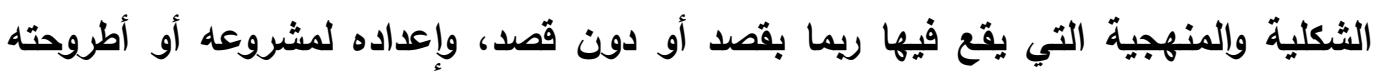

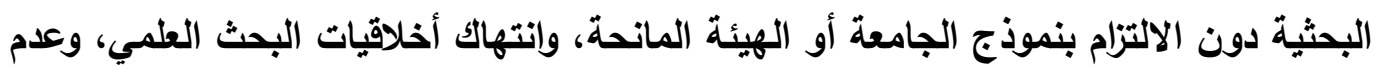

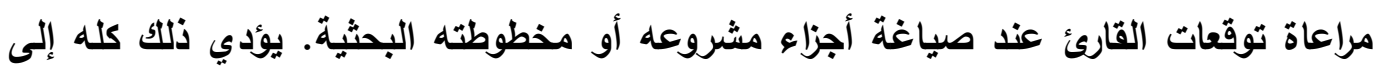
ترهل هيكل المشروع أو المخطوطة البحثية نتيجة اتكالية الباحث على مشرفه أحيانًا أو استعانته بالأخرين لكتابة مشروعه أو مخطوطته وأداء المهام عنه، ومن ثم اللامبالاة تجاه عمله البحثي وعدم تحمل المسؤولية عما ورد في مشروعه أو أطروحته البحثية من أخطاء وريما التتصل

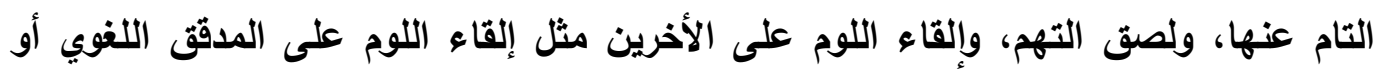

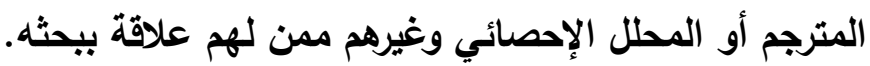

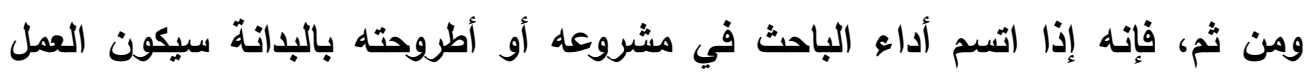

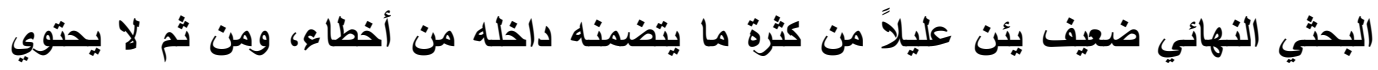
على قيمة علمية مضافة حول موضوعه ولا يثري الأدبيات النظرية والمعرفة العلمية. لهذا، نجد الجدائ

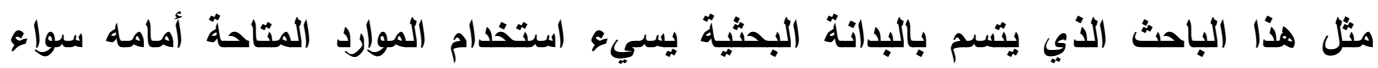

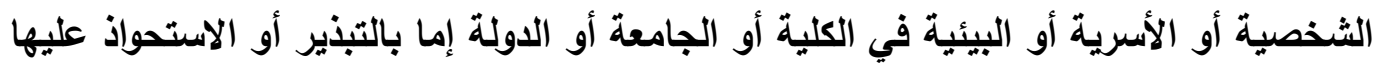

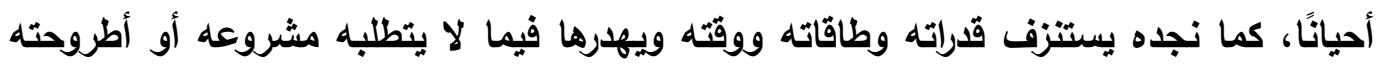

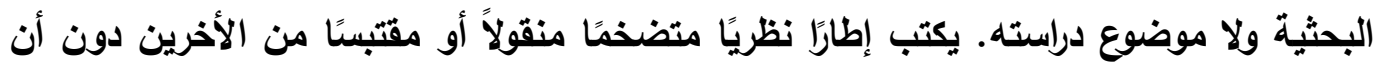

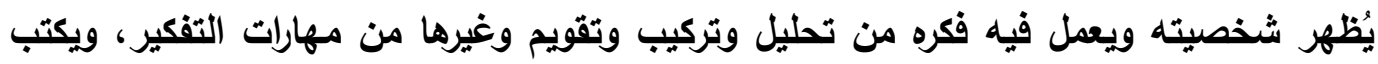
عن ما يقع في نطاق موضوع بحثه وما لا يقع، وكنلك نجده يكتب الدارسات والبحوث البهاب السابقة

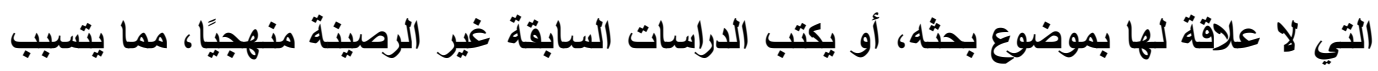

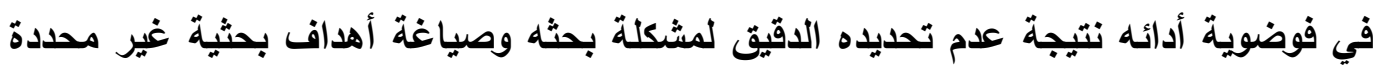


وغير واقعية، وريما نتيجة لاختيار تصميم بحثي غير مناسب وغير اقتصادي لدراسة موضوع

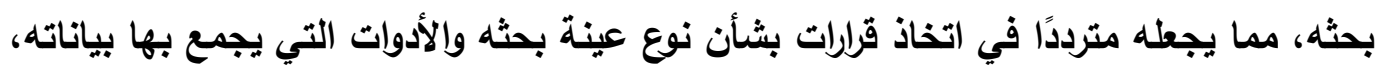

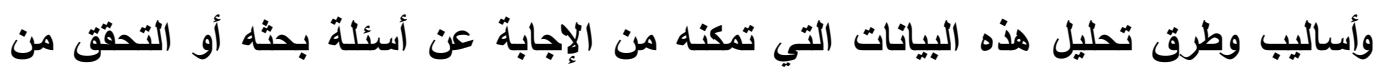

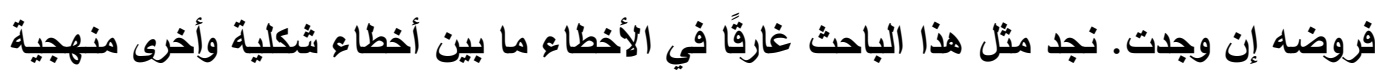

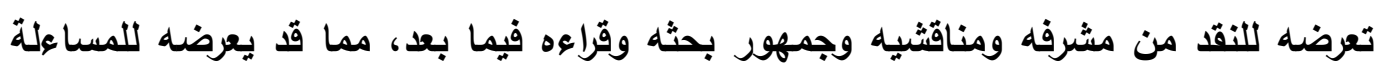
القانونية إذا اخترق قواعد وأخلاقيات البحث العلمي وحقوق الملكية الفكرية للأخرين.

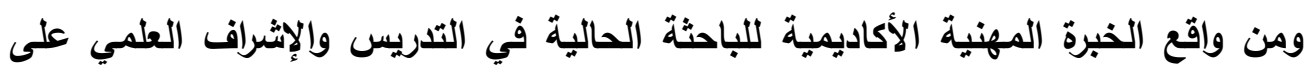

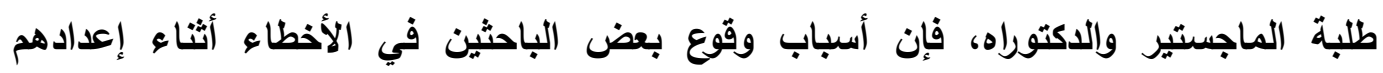

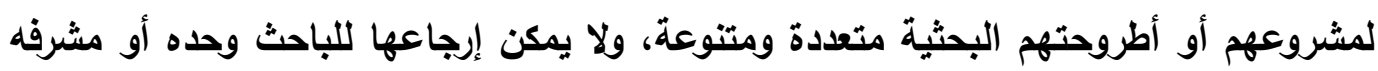

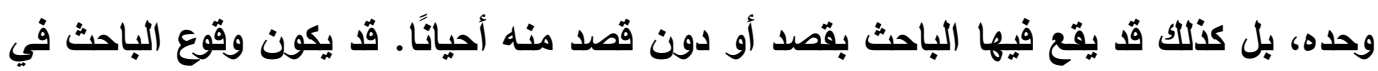
الأخطاء نتيجة عدم العلم بها (1)، أو قد يكون ناتجًا عن تعلم مشوش في مرحلة الإعداد العلمي التي تسبق إعداد وكتابة المشروع أو الأطروحة البحثية (r)، بل وقد تكون هذه الأل الأخطاء

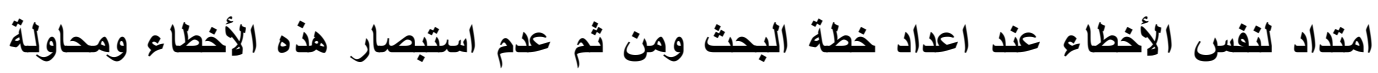

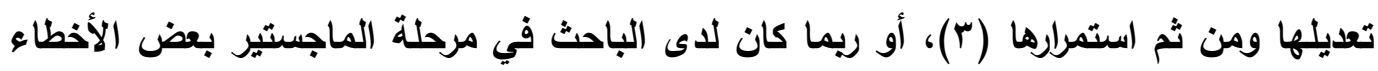

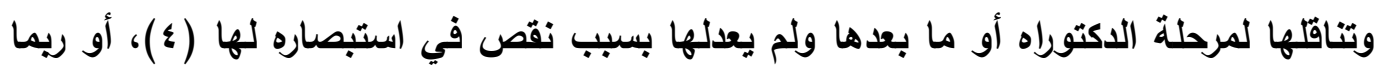
يكون بسبب اهتاء الباحث بباحثين سابقين في كتابتهم لاطروحاتهم واعتقاده أنه طالما

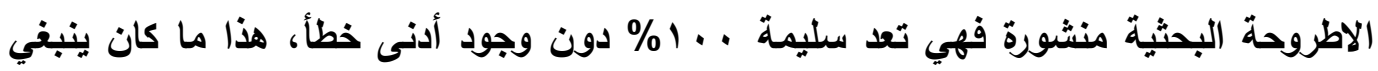

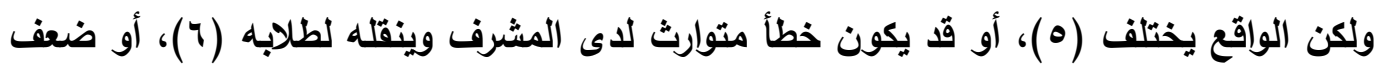

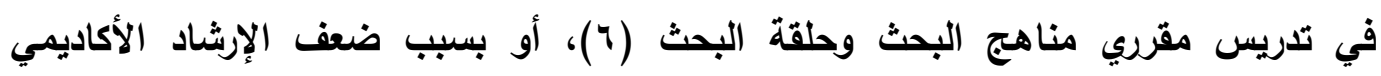

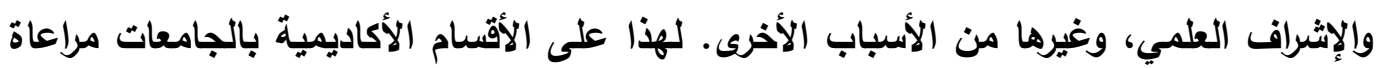

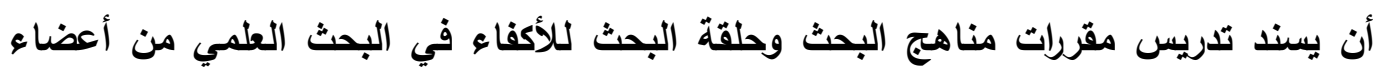

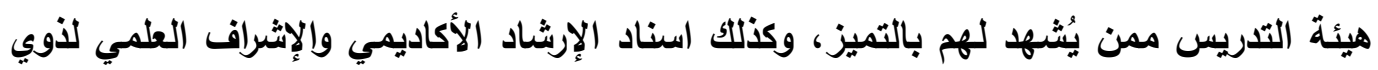

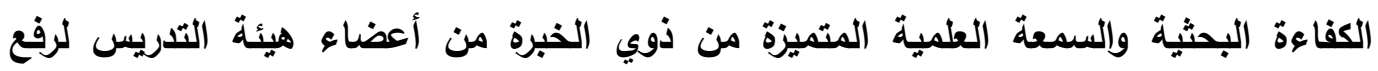
مستوى جودة البحث العلمي وتحقيق الميزة التنافسية البحثية للجامعات. 


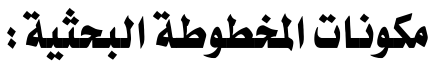

ذكر (Creswell, 2013; 2015; Creswell \& Creswell, 2018) أنه على

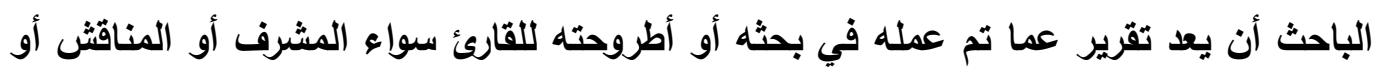

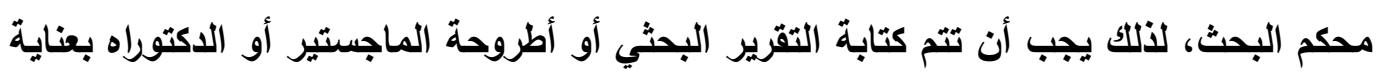

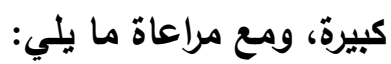
ا.يجب أن يكون تخطيط التقرير على النحو التالي: (1) الصفحات الأولية؛ "r" والنص الرئيسي و "ب" المسألة النهائية. يجب أن يحمل التقرير في صفحاته الأولية العنوان والتاريخ

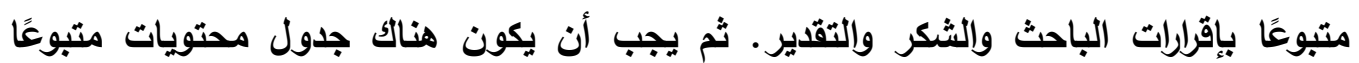
بقائمة الجداول وقائمة الرسوم البيانية والأثكال التوضيحية، إن وجدت والثان يجب أن يحتوي النص الرئيسي للتقرير على الأجزاء التالية:

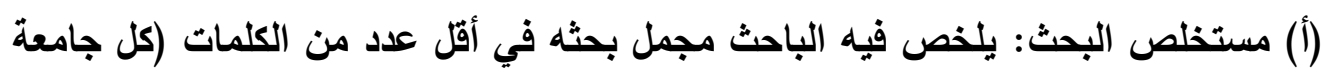

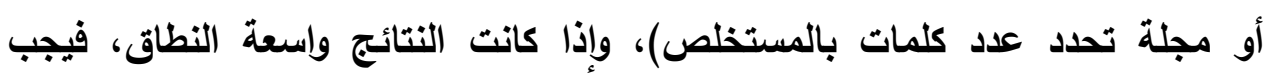
تلخيصها وكتابة أبرز النتائج. (ب) مدخل للاراسة: يجب أن يحتوي على بيان واضح عن مقدمة البحث ومثكلته وأهدافه وأهميته، وذكر مصطلحات وحدود الاراسة بالإضافة إلى جوانب القصور المختلفة في هذا الجزي. (ج) التقرير الرئيسي: ينبغي تقديم الجزء الرئيسي من التقرير في تسلسل منطقي وتقسيمه

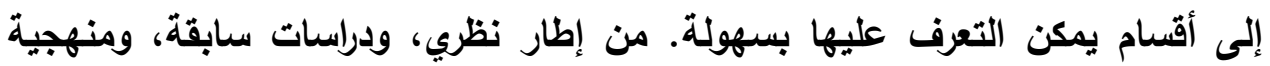
البحث وإجراءاته، والنتائج ومناقشتنها وتفسيرها نظريًا.

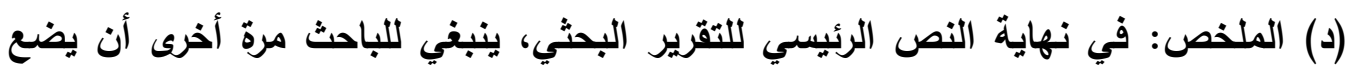
نتائج بحثه بوضوح ودقة. في الواقع، يعد الملخص هو الخلاصة النهائلة النهائة للبحث.

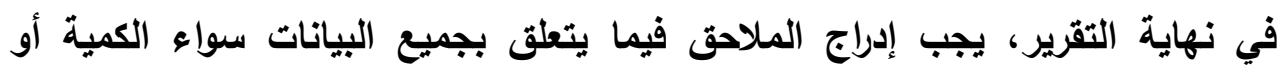

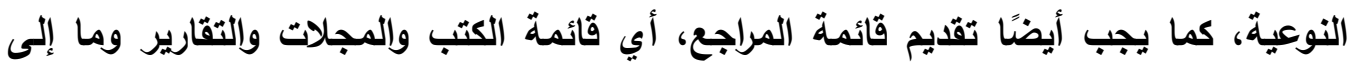
ذلك، التي تم الاستثهاد بها في متن الدراسة. في النهاية، أود التأكيد على الباحثين في

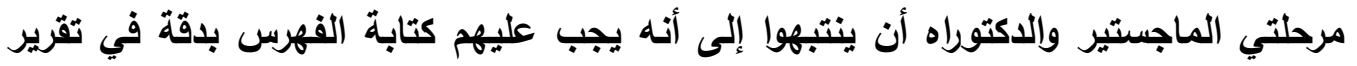


البحث، بحيث لا يختلف عن ترتيب العناصر ومسميات العناوين الرئيسية والفرعية بمتن الدراسة (كثير من الباحثين يقعون في خطأ، إعداد الفهرس بعناوين وترتيب ومسميات لغناصر الاراسة مختلفة لما ورد بمتن البحث.

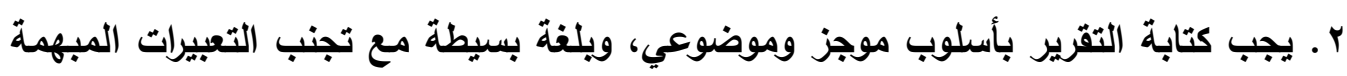

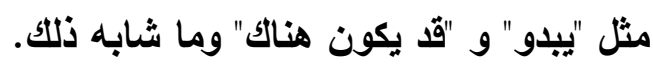

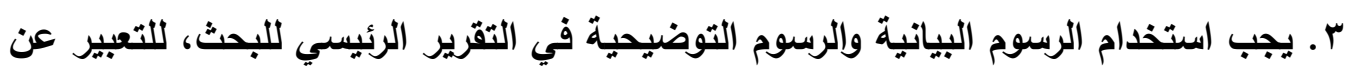
المطومات بثكل أكثر وضوحًا وقوة. ع. يجب ذكر العقبات أو جوانب القصور المختلفة Limitations التي واجهها الباحث أثناء

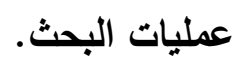

\section{خصائص الاطروحة البحثية الجيلة:}

أثشار (Creswell \& Creswell, 2018) أن هناك عدد من الخصائص للمشروع أو لألطروحة البحثية الجيدة، هي: 1. أن تكون الأطروحة واضحة في موضوعها وغرضها ويمكن التعامل معه وقابل لإدارته وتحقيقه.

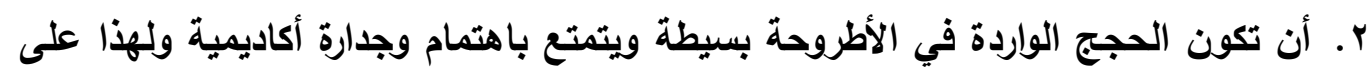

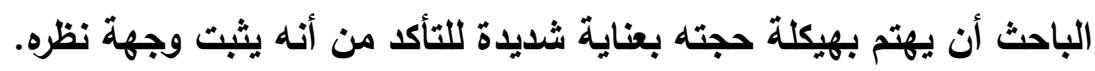

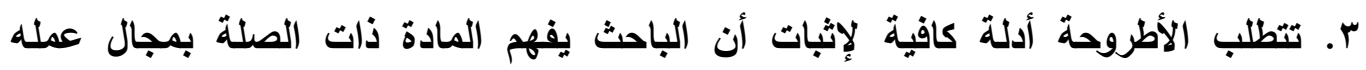

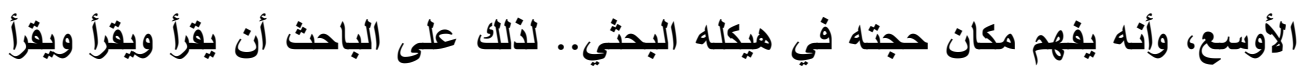
ويقرأ قبل أن يفكر في الكتابة. ؛. تتطلب الأطروحة الجيدة الكتابة الأكاديمية الدقيقة والرصينة، على الباحث أن يكون واضحًا

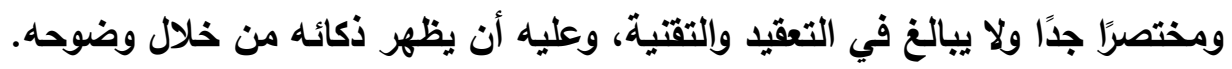
هـ أن تكون استتاجات الأطروحة الجيدة قوية. إذ أن بعض الباحثين ولئن يتكاسلوا في نهاية

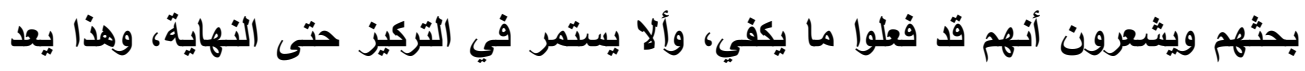

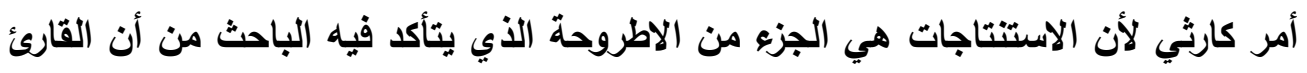


يفهم بدقة المكان الذي يريده الباحث أن يكون فيه، ولهذا أوصي الباحثين بأن يحتفظوا بأيدي القراء حتى آخر كلمة.

\section{الأخطاء الشائعة في المشروع أو المخطوطة البحثية:}

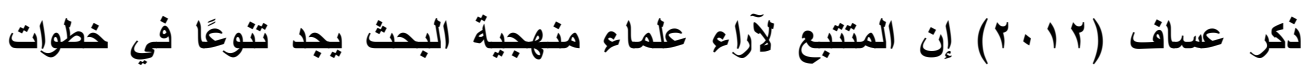

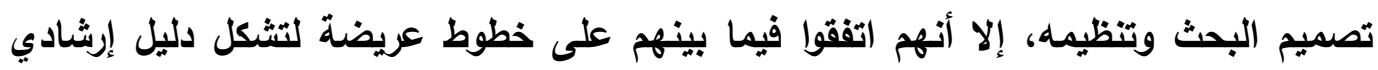
للباحثين أثناء إعداد رسائلهم ويحوثهم. للبحث العلمي خطوات محددة تعد خارطة طريق تهائ الهي

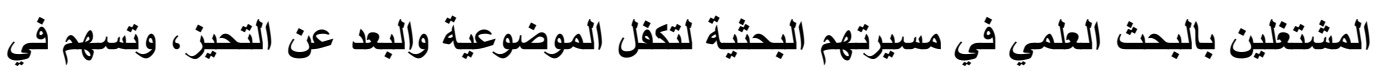

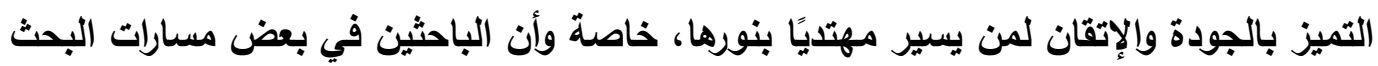

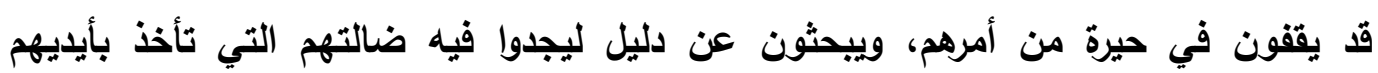
لمواصلة المسيرة البحثية الثاقة والممتعة. ويمكن حصر هذه الثئه الخطوات في الخطوات العريضة، الآتية: اختيار مشكلة البحث وتوضيح ماهيتها، تحديد أهداف البحث وأهميته، مراجعة الأدبيات

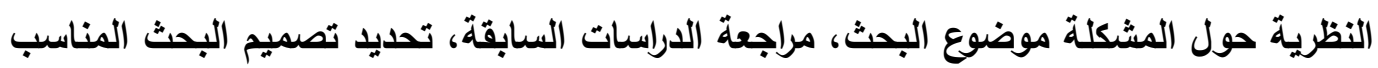

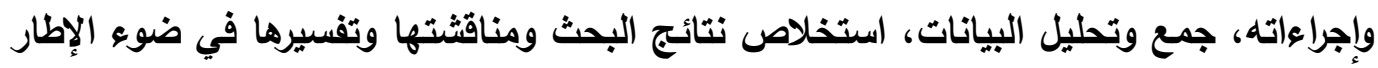

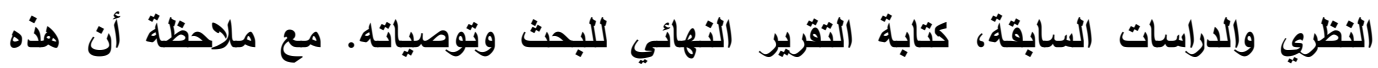
الخطوات ليست ثابتة أو أن الباحث يجب عليه أن يلتزم باتباعها بنفس الترتيب، لأن عملية

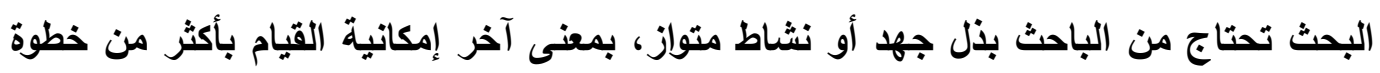

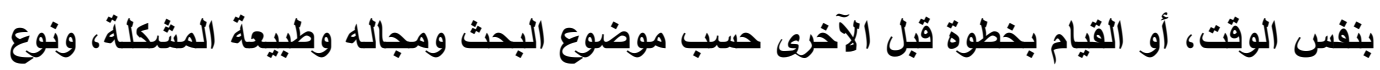
تصميم البحث ومنهجيته وإجراءاته.

في كل خطوة من هذه الخطوات قد يقع الباحث في أخطاء معظمها غير مقصود منه، ولهزا

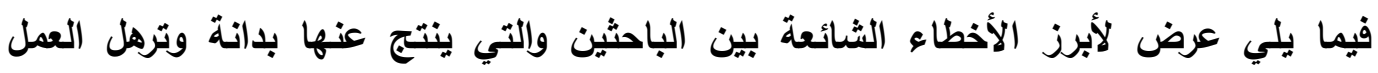
البحثي وضياع فرص الحصول على الميزة البحثية التنافسية لهم ولجامعاتهم أو الهيئات

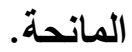

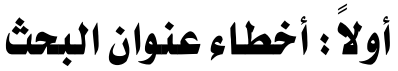

العديد من الباحثين لا يولون اهتماما كبيرًا في صياغة عنوان بحوثهم. إن عنوان البحث علامة مهمة في البحث تساعد على أن يحافظ الباحث على تركيزه على الهاف الألى الأساسي 
لاراسته. العنوان الأولي للبحث قيد التقدم ويمكن مراجعته مع تقام الدراسة. تتنوع الأخطاء

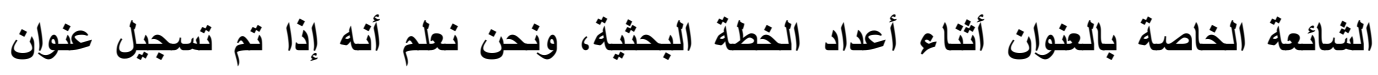

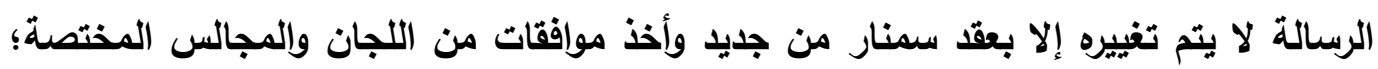

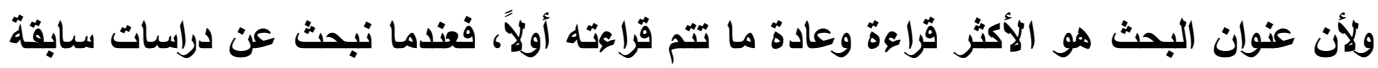

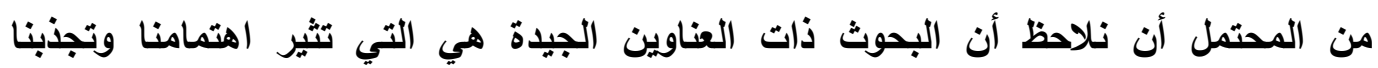

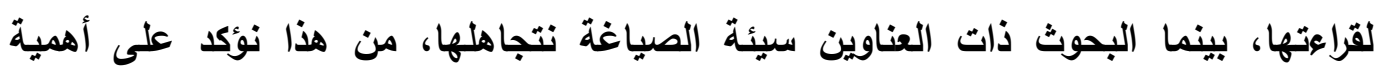
صياغة عناوين جيدة لبحوثنا. عليه يجب على الباحثين صياغة عناوين بحوثهم بكفاءة عالية واستثارة أحد المختصين في اللغة العربية في هذه الصياغة. من أبرز الأخطاء في صياغة الباغة

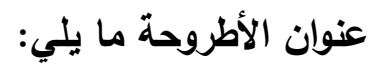

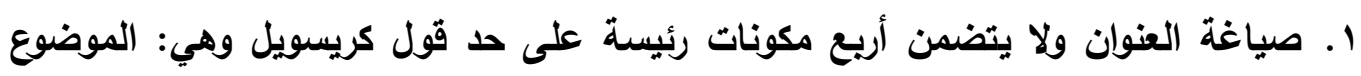

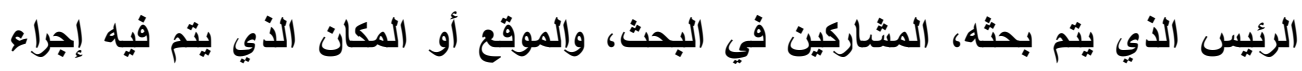
البحث، والنهج العام. إلا إذا كان وصف المثاركين يتضمن المكان (مثل معلمي العلوم

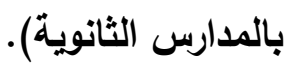
r. صياغة العنوان في عدد كبير من الكلمات قد تصل إلى فقرة، ولا تصف بثكل مناسب

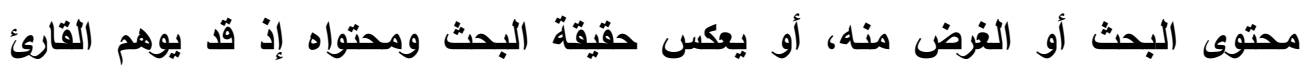

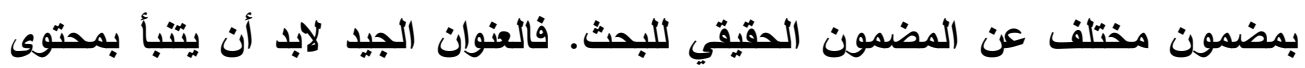

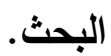

r. ألا يحتوي العنوان على الكلمات الرئيسة المهمة مما يصعب تحديد موقعها داخل البحث. ؛. يصوغون عناوين غير واضحة وغير دقيقة وغير محددة. هـ يصوغون عناوين طويلة مملة أو قصيرة مخلة. آ. يصوغون عناوين بحوثهم وتتضمن كلمات مكرة أو اختصارات علمية غير واضح مغناها للقارئ.

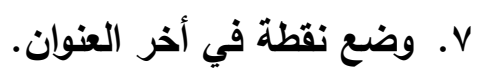

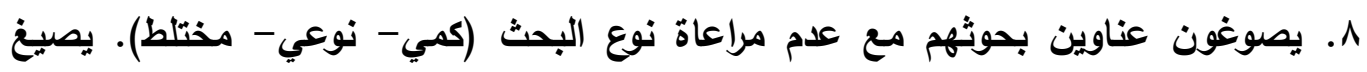

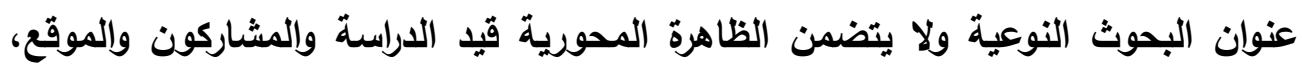

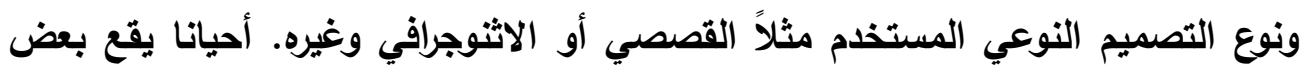


الباحثين في خطأ صياغة عنوان البحث النوعي ويذكرون فيها علاقة، مقارنة، تنبؤ وغيرها

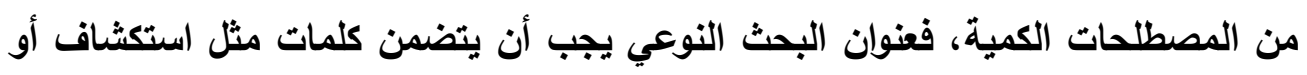

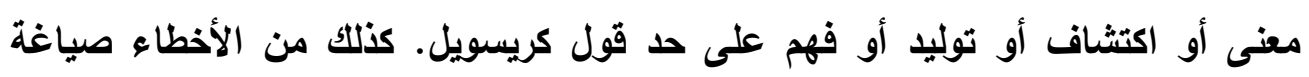

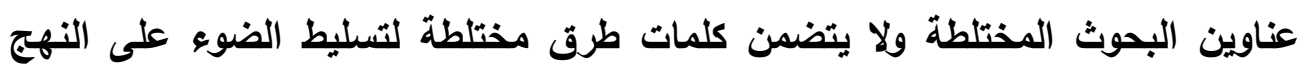

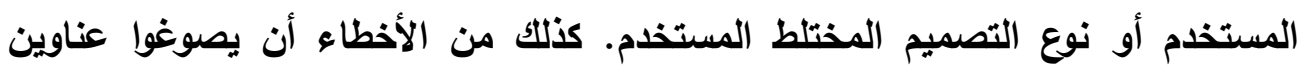

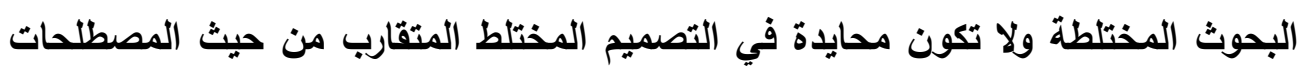

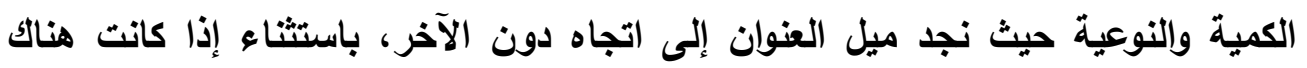

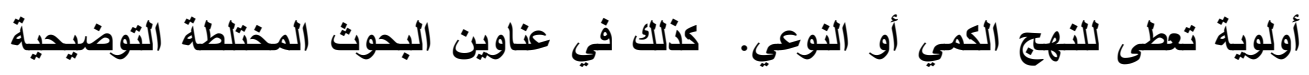

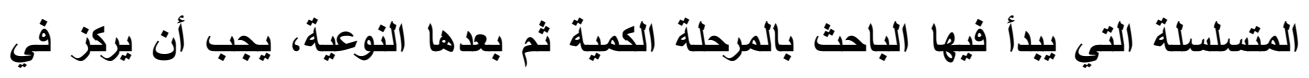

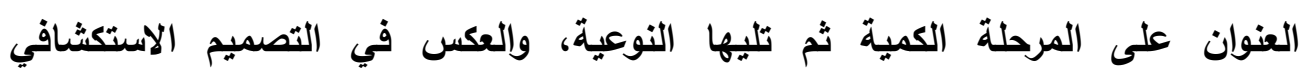

$$
\text { التسلسلي. }
$$

ثانيًا : أخطاء صياغة مقدمة البحث

المقدمة تهيئ ذهن القارئ للشعور بوجود مشكلة. يجب أن يهتم الباحث جدًا بصياغة

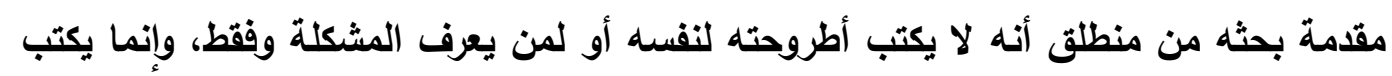

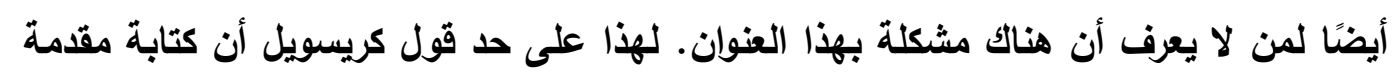

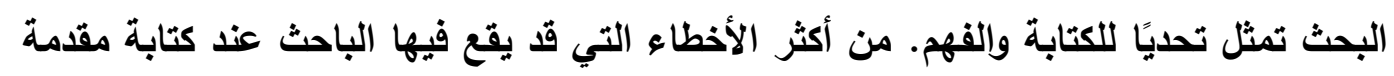

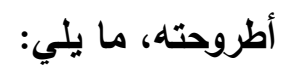
1. ألا تتضمن المقدمة الحديث عن كل متغيرات بحثه بشكل متوازن، أو التغافل عن إحداها، أو الاهتمام الزائد بالحديث عن إحداها. r. لا يكتب مقدمة أطروحته على هيئة مثلث مقلوب يبأ من العام ثم الخاص فالأخص ليهئ القارئ لمشكلة بحثه.

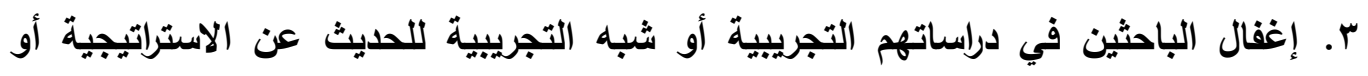

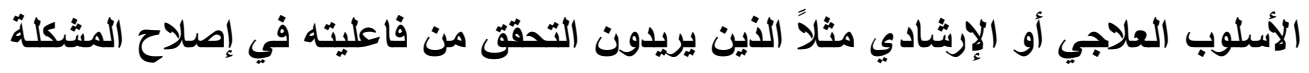
موضوع أطروحته، فنجدهم يركزون فقط في الكتابة عن المتغير التابع. 
؛. من أبرز الأخطاء التي قد يقع فيها الباحثون عند صياغة مقدمة البحث المختلط هو أنه الهي

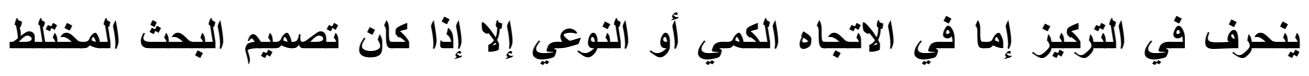

$$
\text { المستخدم هو التصميم التقاربي. }
$$

ه. كتابة مقدمة طويلة قد تزيد أحيانًا عن خمس صفحات. وقد أثشار كريسويل أن المقدمة الجيدة تكون مختصرة لا تزيد عن صفحتين أو ثلاث وفقًا لإجمالي حجم البحث.

ثاثثًا: أخطاء صياغة المثكلة البحثية

الباحث مثل الطبيب، يجب على الباحث فحص جميع الأعراض (المقدمة إليه أو التي

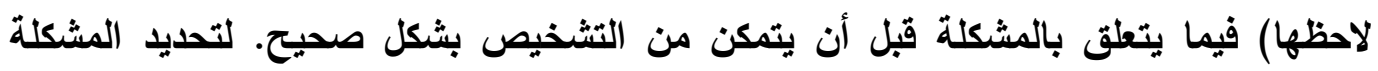

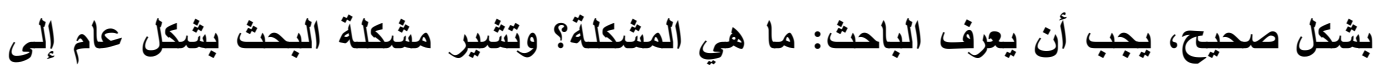

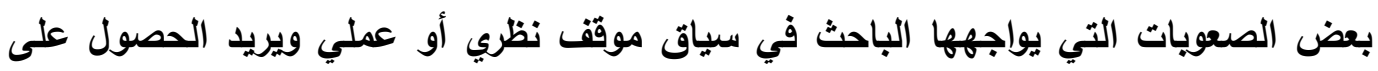
حلول لها. لهذا تعد مهمة صياغة أو تحديد مشكلة البحث خطوة ذات أهمية قصوى في عملية البحث بأكلها، ويجب على كل باحث معرفة أن التحديد الخاص بمثكلة بحثه لا يمكن استعارته من بحث أو دراسة أخرى إذ يجب أن تنبثق المثكلة من ذهن الباحث مثل نبات ينبع من بذرته.

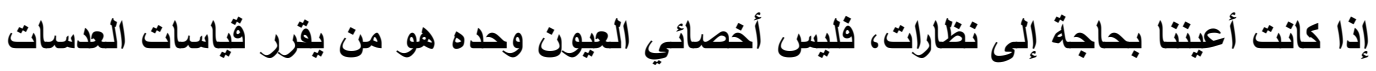
التي نطلبها، بل علينا أن نرى بأنفسنا ونمكنه من أخذ القياسات الدقيقة لنا من خلال التهان التعاون

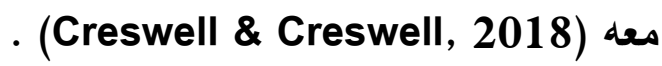

مشكلة البحث هي القضية التي تثير الحاجة إلى إجراء دراسة للوصول إلى حلول لها.

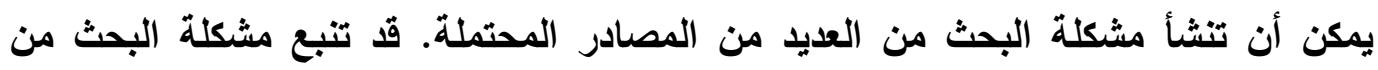
تجرية عاشها الباحثون في حياتهم الثخصية أو في أماكن عملهم أي من خلال الخبرة

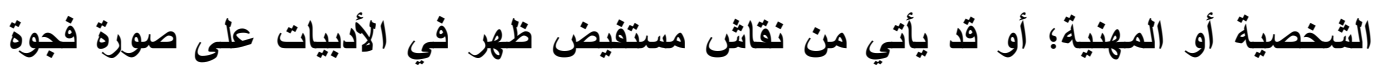

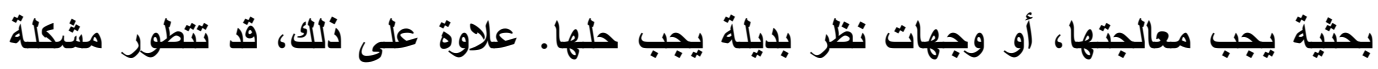
البحث من المناقثات، ومن ثم يمكن القول بأنه غالبًا ما تكون مصادر مشكلات البهات البحث متعددة.

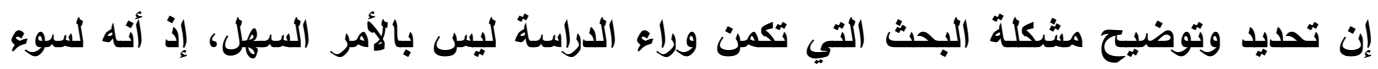

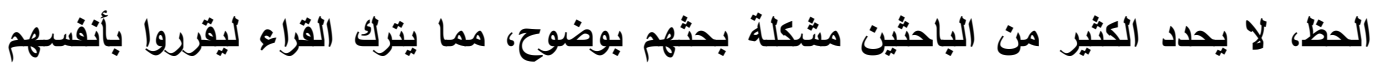

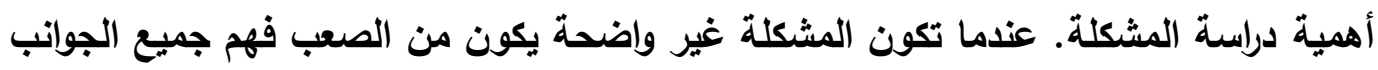

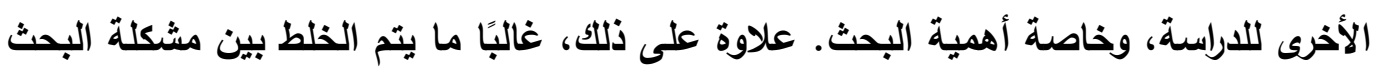




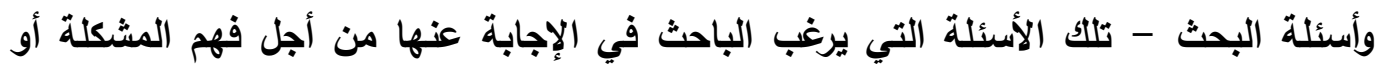

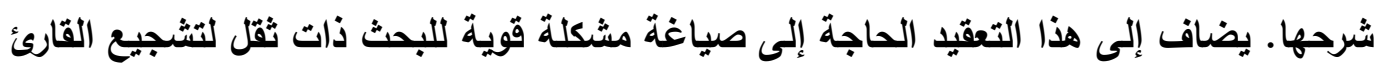

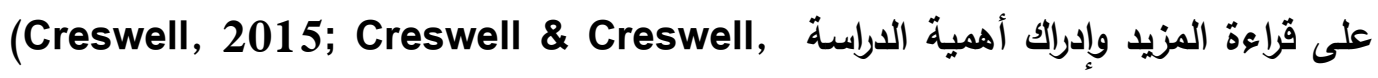

.2018)

ومن أبرز الأخطاء التي يقع فيها بعض الباحثين عند صياغة مشكلة بحثهم، ما يلي: 1. التهويل أو التهوين في عرض مشكلة البحث عند صياغتها.

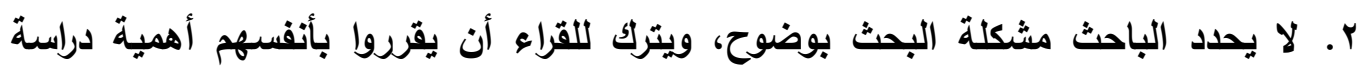

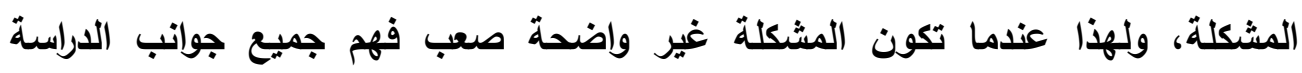
الأخرى، وخاصة أهمية الدراسة. r. الخلط بين صياغة مشكلة البحث ومقدمته، فنجد الباحث يصيغ مشكلة بحثه بنفس طريقة صياغة المقدمة، أي نقل فقرات عن متغيرات البحث، دون توضيع مبررات اختيار مشكلة

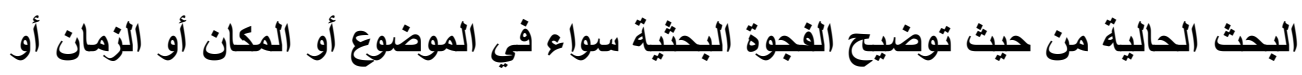

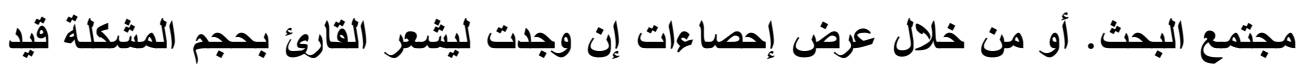

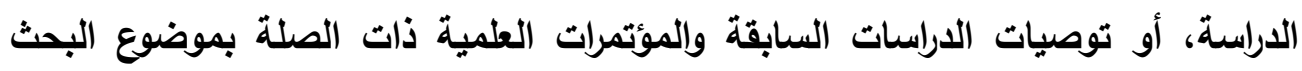

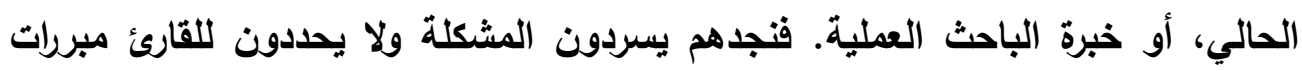

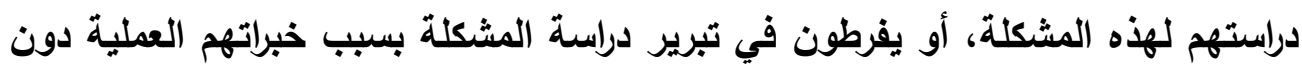

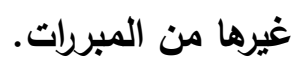
ء. عدم فحص جميع الأدب النظري السابق للمشكلة موضوع الدارسة سواء الأدب المتطقق بالمفاهيم والنظريات أو البحوث والاراسات السابقة. ه. الخلط بين صياغة مشكلة البحث وأسئلته، فالأسئلة يحاول الباحث الإجابة عنها فيما بعد العدافئ لفهم مشكلة بحثه وشرحها.

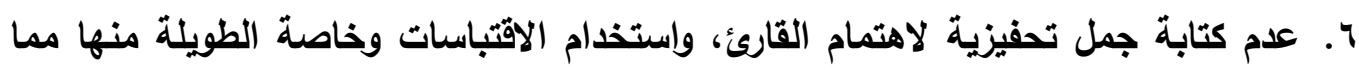

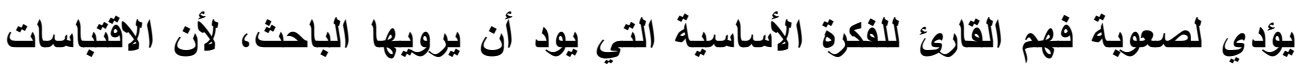
تثثير احتمالات كثيرة للتفسير ويالتالي تخلق بدايات غير جيدة للفئل للقارئ. v . استخام الكلمات غير اصطلاحية أو العبارات المبتذلة. 
^. تأطير مشكلة البحث بطريقة لا تتناسب مع منهج البحث، ونوع التصميم البحث المستخدم. مثلاً، في البحوث التجريبية يجب أن يتحدث في صياغة مشكلته عن أسباب تصميم

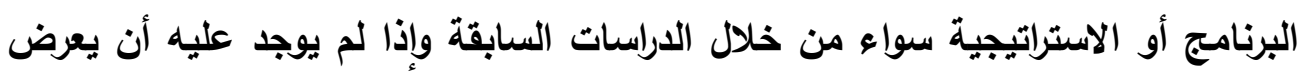
باختصار في مشكلة بحثه نتائج الدراسة الاستطلاعية التي قام بها ليثبت للقارئ مبرلات الاتهات بناء الاستراتيجية الحالية أو البرنامج لمعالجة المشكلة موضوع البحث. وكذلك في البحوث النوعية والمختلطة لا نجد الباحث يبرر للقارئ سبب استخدامه لهذا النهج دون غيره في مشكلة بحثه من خلال الفجوة البحثية وإبراز الفروق في المنهج المستخدم في الاراسات

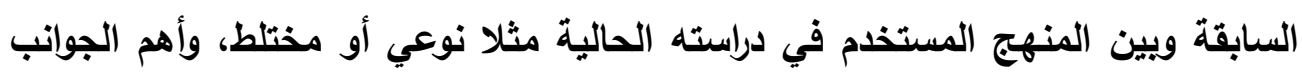
التي يتميز بها بحثه الحالي وموقعه من الدراسات السابقة.

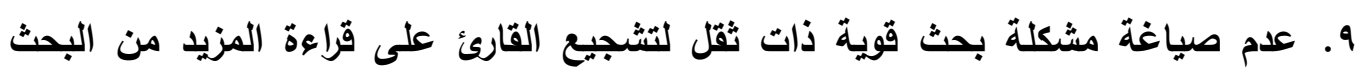
وإدراك أهميته، وذلك من خلال القصور في الدراسات السابقة التي جمعها قبل أن يختار مشكلة بحثه، ومن ثم جاعت دراسته لسد الفجوات الموجودة في الأدبيات حول موضوع

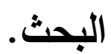

\section{رابعًا : أخطاي صياغة أسئلة البحث}

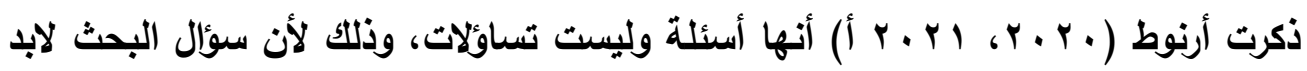
وأن يصل الباحث إلى إجابة محددة له، لألك هي أسئلة. أما تساؤلات تعني أنه ليس لها لها إجابات محدة وحولها جل وخلاف، وهذا يخالف ما يهدف إليه البحث العلمي؛ إذ أن الهُف من البحث العلمي يتمثل في البحث عن حلول لمشكلة البحث. فتحديد أسئلة البحث لا تبدو قيمتها واضحة ما لم تعد الإجابة عنها ضرورية. ومما يساعد على وضوح مشكلة البحث، سرد الأسئلة التي

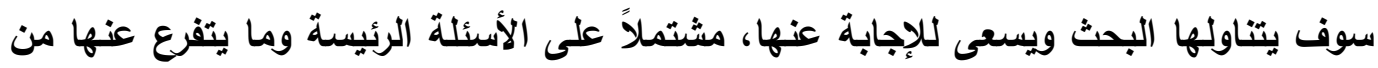

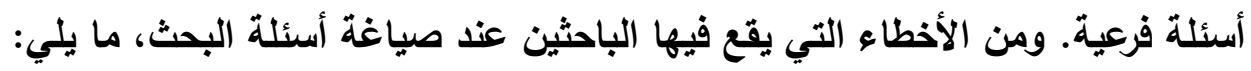
1. استخدام مصطلح تساؤلات البحث بدلاً من أسئلة البحث.

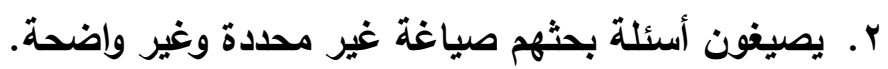
r. ب. لا يصيغونها صياغة مباشرة.

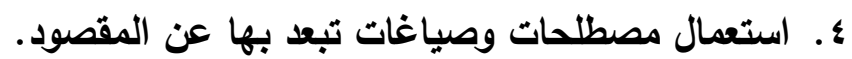


ه. صياغة الأسئلة بنفس طريقة صياغة الفروض فيما عدا أداة الاستفهام وعلامة الاستفهام. من الصح أن الباحث عند صياغة الأسئلة يبعد عن الكلمات التي تثير إلى الالالة الإحصائية مثل دالة أو جوهرية وغيرها، وكذلك عدم ذكر مستوى الدلالة في الأسئلة. 4. في صياغة أسئلة البحوث المختلطة يقتصر على ذكر أسئلة كمية ونوعية فقط منفصلة. وذكر (Creswell \& Clark, 2018) أن في البحوث المختلطة يصيغ الباحث ثلاثنة أنواع من أسئلة البحث - أسئلة نوعية تبدأ بكلمات مثل ماذا ولماذا وكيف وغيرها من أدوات السؤال الكيفية، قد تتراوح في المتوسط بين ه - V أسئلة يتم صياغتها في ضوع

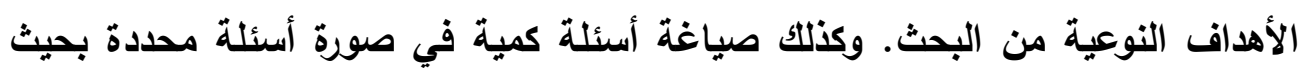

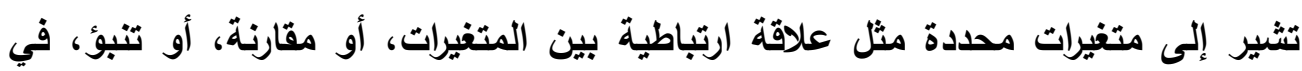

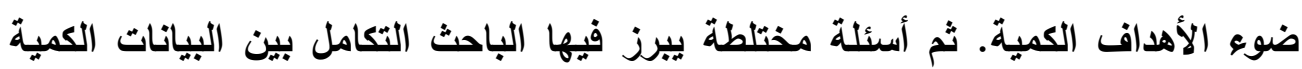
والنوعية، وهذا حسب نوع التصميم المختلط: مثلا التصميم المتقارب يتضمن دمج قاعدتي لئي البيانات، بينما سؤال التصميم التوضيحي التسلسلي يتضمن استخدام البيانات النوعية للمساعدة في شرح وتوضيح النتائج الكمية، أما في سؤال التصميم الاستكشافي التسلسلي يوضح كيف سيتم تعميم النتائج النوعية الأولية على عينة أكبر من خلال جمع البيانات الكمية وتحليلها. ويتم ترتيب هذه الأسئلة وفقا لنوع التصميم المختلط المستخدم التقاريب

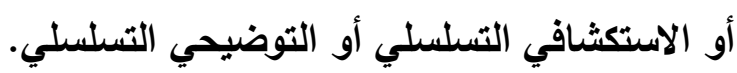

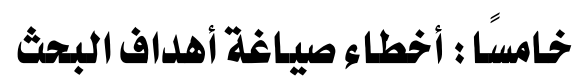
ذكرت أرنوط (·r · r أن أباحثين يجب أن يصيغوا أهدافهم وتتوافر فيها الخصائص التالية المتمثلة في حروف كلمة SMART، والتي تعني: 1. أن تكون أهدافهم محددة Specific

r. أن تكون قابلة للقياس Measurable.

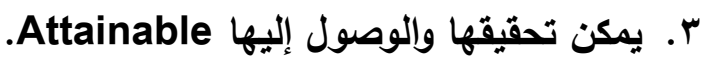

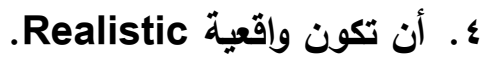

هـ أن تكون أهداف محددة بوقت أن أنهون ولهذا فإن من أبرز أخطاء كتابة أهداف البحث بين الباحثين، ما يلي: 
ا ـ يصيغون أهداف غير واقعية لا يمكن تحقيقها، إذ نجدهم يبالغون فيما يذكرونه من أهداف يصعب أو يكاد يستحيل تحقيقها. ولذلك ينبغي على الباحث بعد أن يكمل خطوات إعداد بحثه أن يراجع ما كتبه من أهداف. r. يضعون أهدافاً غامضة وغير محدة، وليست مرتبة منطقياً، أو مرتبة حسب أهميتها ويضمونها أهدافاً تخرج عن نطاق المشكلة المدروسة.

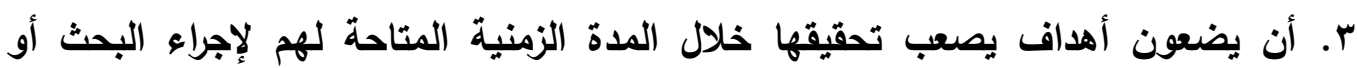
الاراسة، ومن ثم يستحيل تحقيق هذه الأهداف، وتؤدي إلى إعاقة استكمال البحث.

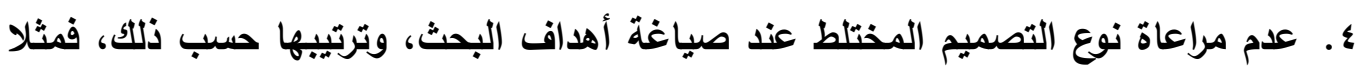
التوضيحي التسلسلي لا يبدأون بالأهداف الكمية ثم النوعية ولا يذكرون أهداف كمية أكثر أثرئ من النوعية، والتصميم الاستكشافي التسلسلي يبدأون بالكمي قبل النوعي وهذا خطأ لأن لأن التهيل المفروض يبدأون بالنوعي ثم الأهداف الكمية ويعطون أولوية أكثر للأهداف النوعية.

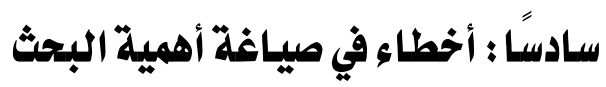
من أبرز ما يقع فيه الباحثين من أخطاء عند صياغة أهمية مشروعاتهم البحثية، ما يلي: ا ـ وضع أهمية البحث قبل أهدافه في المخطوطة. فمن المفترض أن يحدد أهداف البحث وفي مني مني ضوئها تتجلى أهميته البحث، وهذا هو الترتيب المنطقي. r. يقع الكثير من الباحثين في خطأ الخلط بين أهمية وأهداف البحث، حيث يعتبر ذلتك من لن

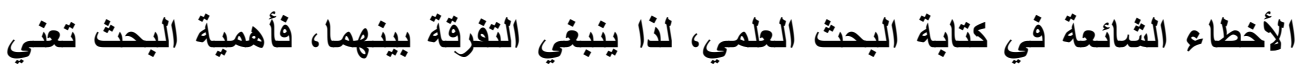

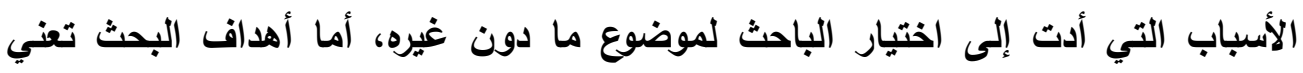
الغاية من إجراء البحث. r. عدم توضيح ما يمكن أن يقدمه البحث في حل مشكلة أو إضافة علمية، أو المبالغة في ذلك. ـ. عدم ذكر ما يضيفه البحث من إثراء لأدبيات البحث النظرية حول متغيرات بحثه وموضوعه، وأحيانًا المبالغة في ذلك. ه. عدم توضيح أهمية دراسة مجتمع البحث وعينته. 7 . . عدم ذكر الباحث أهمية بحثه من حيث تقديم أدوات قياس جديدة في التخصص إن وجئه وجدت. 
V. عدم ذكر أهمية بحثه من حيث فتح أفاق بحثية جديدة أمام الباحثين حول موضوع البحث الحالي. ^. عدم توضيح بماذا سوف تفيذ ما توصل إليه البحث من نتائج الأفراد أو الهيئات والمراكز ذات الصلة عند صياغته للأهمية. 9 . . عدم مراعاة نوع التصميم عند كتابة أهمية البحث. مثلا أهمية ما تضيفه الدراسة النوعية

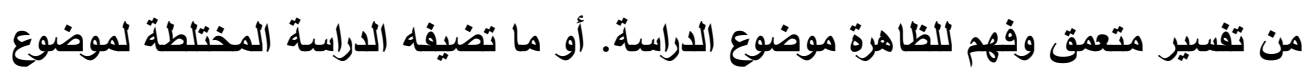
الدراسة من أهمية في دمج قاعدتي البيانات الكمية والنوعية وما يحققه ذلك من أغراض.

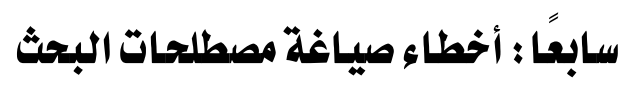
كثير هي الأخطاء التي يقع فيها الباحثين عند تعريف مصطلحات بحثهم، ومن أبرز هذه الأخطاء ما يلي: ا ـ سرد عدد كبير من التعريفات القاموسية وغيرها للمصطلحات، ومن الصح كتابة تعريفين اصطلاحيين ثم التعريف الاجرائي إن وجد. r ـ تعريف جميع المصطلحات الواردة في العنوان. ومن الصح أن الباحث لا يُعرِف في بحثه إلان المصطلحات التي فيها خلاف بين المتخصصين حول معناها، وهنا يجب أن يعرفها الباحث اصطلاحيًا، مع ملاحظة أن المعرف لا يعرف.

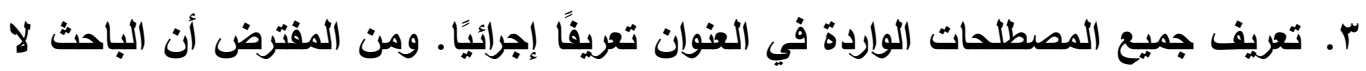
يعرف إجرائيًا إلا المتفيرات التي سيتم قياسها في البحث. ويجب أن يعلم الباحث أن لاينا

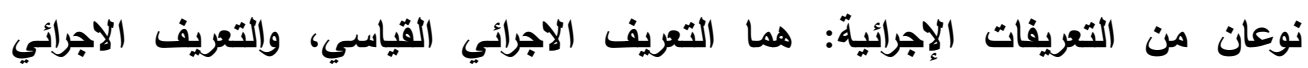
التجريبي. ء. . عدم استعارة التعريفات الإجرائية لمعدي أدوات القياس التي يستخدمها لقياس المتغير في بحثه، ويقوم الباحث بتعريفها بنفسه. وهذا خطأ يقع فيه الباحث. ه. عدم مراعاة نوع التصميم البحثي عند تعريف المصطلحات. مثلا في التصميم الكمي يضع الباحث تعريفات نهائية لمصطلحات بحثّ، أما في التصميم النوعي نجد أن الباحث في هذا القسم يقدم تعريف غير محدد لمصطلحات بحثه لأنه بعد استخلاص نتائج البحث تتحدد تعريف المصطلحات بدقة أكبر على سبيل المثال في النظرية المجذرة، وفي التصميم 
المختلط عليه أن يراعي أن هناك مصطلحات تعرف تعريف محدد في جزء الدراسة الكمية ومصطلحات الحلقة النوعية تظل غير محددة حتى استخلاص النتائج. ثامنًا : أخطاء صياغة حدود البحث

تتعدد الأخطاء التي يقع فيها الباحثين عند صياغة حدود البحد البهاء البحث، منها: 1. أخذ الباحث نسخ ولصثق من عنوان البحث وإضافته للعدود الموضوعية.

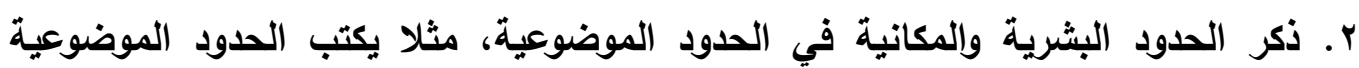
ويذكر لاى طلبة المرطلة الثانوية بمدينة ابها. r. بصف عينة بحثه في الحدود البشرية. ؛. عام مراعاة نوع تصميم البحث. مثّلا في البحث النوعي هلهفه ليس تعميم النتائج كما في

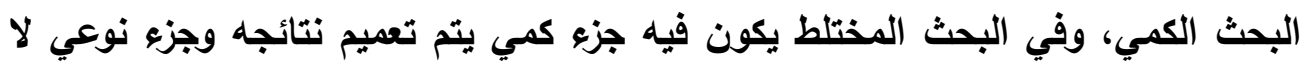
يعمم ولكن تم إجراء المرحلة النوعية لزيادة وضوح وتفسير النتائج الكمية في المرحلة

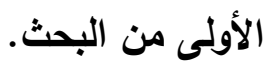

\section{تاسعًا : أخطاء صياغة الإطار النظري للبه البحث}

من أكثر فصول الأطروحة البحثية التي يقع الباحثين فيها في أخطاء هو الإطار النظري

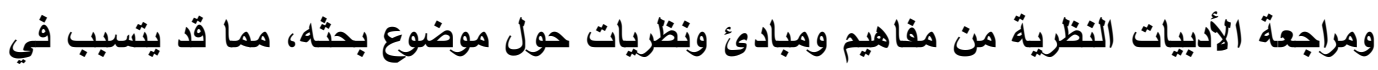
ترهل أطروحته بسبب بدانة وتضخم هذا الفصل، ومن أبرز هذه الأخطاء، ما يلي: ونيات

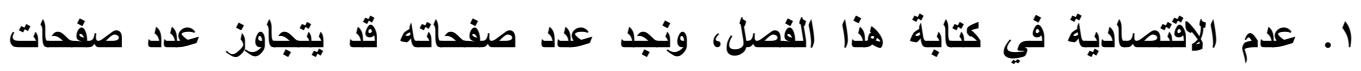
الفصول الأخرى بكثير مما يخل بالتوازن ويرتبك القارئ من كثرة ما يورده الباحث من تفاصيل كثيرة أحيانًا لا ترتبط بيحثه ويغرق الباحث في سردها. r. عدم اختيار أحد الأطر النظرية المعروفة حول متفيرات البحث التي سيستخدمها في تفسير نتائجه.

r. عام توظيف الإطار النظري في تفسير ما توصل إليه من نتائج. ؛. عدم التوازن في الكتابة عن متغيرات بحثه، مثُلا الإسهاب في الكتابة عن أحد المتغيرات

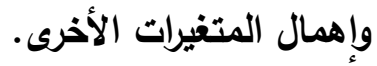
ه. الانتقال المفاجئ بين المحاور دون مراعاة الربط أو الترتيب المنطقي. 
\. كثثرة الاقتباسات وطولها من نفس المرجع أو من الاعتماد على عدد قليل من المراجع في الإطار النظري. مما يتسبب في زيادة نسبة الاستلال في الاطروحة.

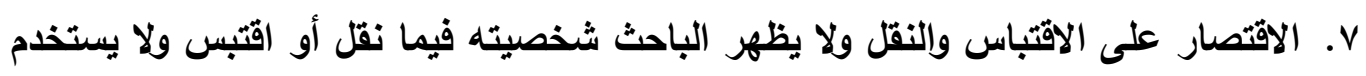

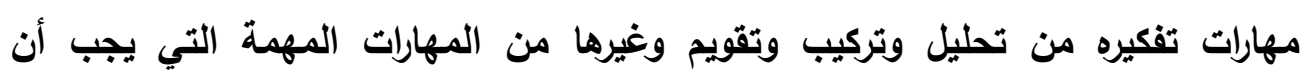
يستخدمها كل باحث عند كتابة إطاره النظري.

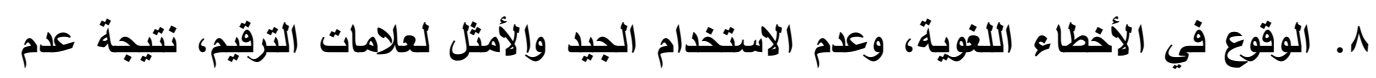

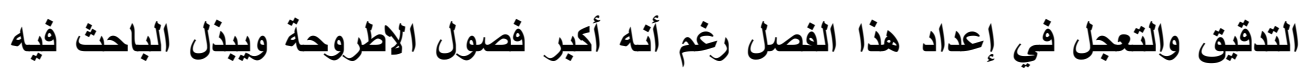
جها كبير. 9. عدم مراعاة قواعد النقل والاقتباس، وأحيانًا عدم الحفاظ على الملكية الفكرية للأخرين.

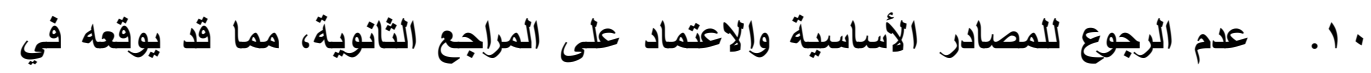
الأخطاء في النقل والاقتباس أو اختراق الملكية الفكرية للأخرين.

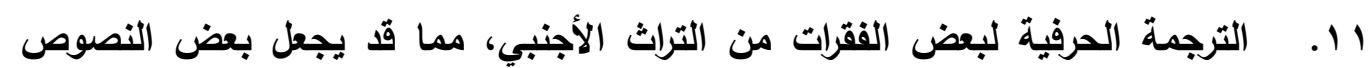
الواردة المترجمة غير مفهومة المغنى للقراء.

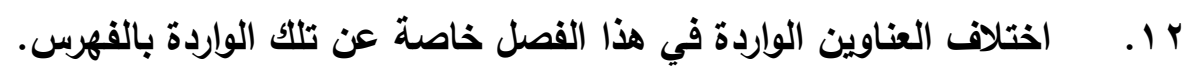

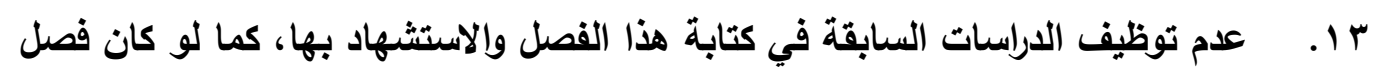
الإطار النظري مستقل تماما عن بقية فصول الاراسة.

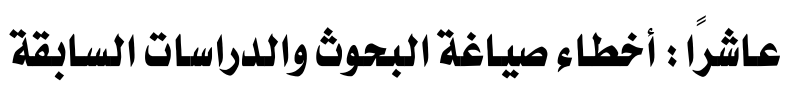

من أكثر الأخطاء الثائعة في مراجعة وكتابة فصل الدراسات السابقة، ما يلي: 1. سرد عدد كبير من الدراسات التي لا علاقة لها بالمشكلة موضوع البحث. وذلك نتيجة أن الن التهات

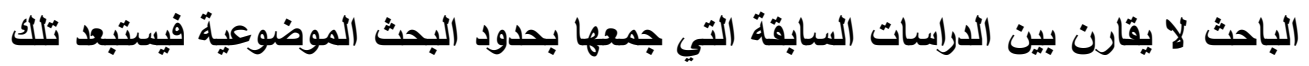
التي لا ترتبط بموضوع بحثه، والمكانية ليستبعد تلك التي أجريت في مكان أخر في حالة التهات توافر عدد كبير من الدراسات التي أجريت في نفس مكان دراسته، ويالحدود الزمنية

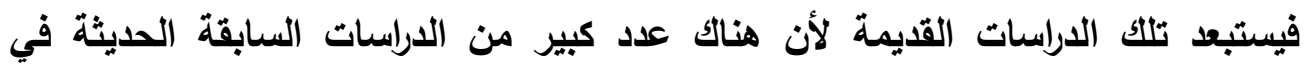

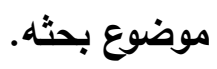
r ـ عدم الترتيب الزمني للاراسات والبحوث السابقة. 
r. عدم الدقة في كتابة الدراسة السابقة وتفاصيلها ريما لنقلها من دراسات سابقة كانت هي في الأصل غير دقيقة. ع. كتابة الدراسة السابقة ولا تشتمل على بعض التفاصيل مثل من قام بها والسنة والههف

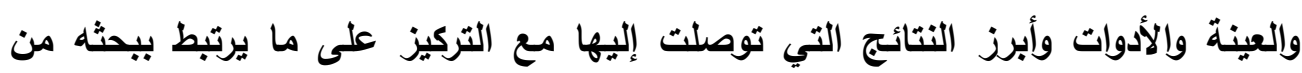

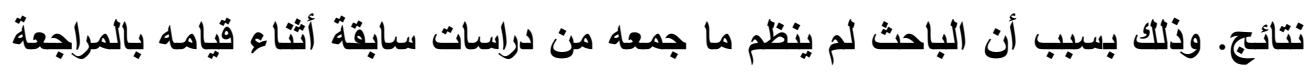

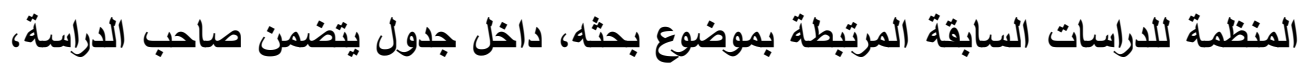

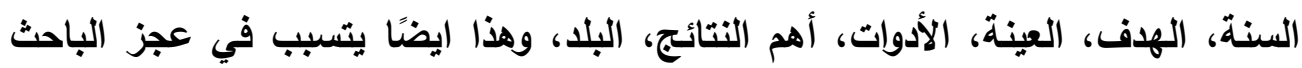
عن توظيف هذه الدراسات في كتابة مشكلة بحثه وتبرير اختيارها للقارئ من جهة وكتابة

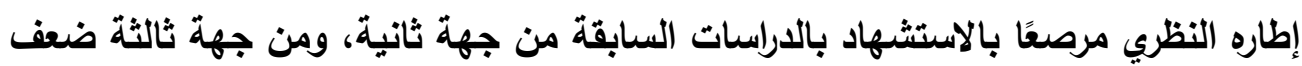

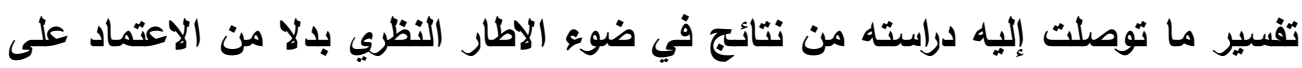
التفسير الأتي الأي يقع فيه كثير من الباحثين. ه. الاسهاب في سرد جميع ما توصلت إليه الدراسة السابقة من نتائج. 7 ـ. عدم إبراز جوانب الاتفاق والاختلاف بين الاراسات السابقة المرتبطة بموضوع الاطروحة وبين دراسته الحالية، وكيف استفاد من هذه الدراسات السابقة. V. الوقوف في مراجعة الدراسات السابقة المرتبطة بموضوع البحث عند عام تشجيل الخطة، وله وعدم الاستمرار في البحث عن دراسات جليدة مما يجعل بعض الباحثين مثلا يتوقف في

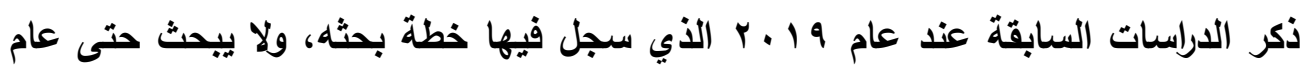
ا Y . الذي سلم فيها مخطوطته، مما يجعله عرضة للنقد من مشرفه ومناقشيه.

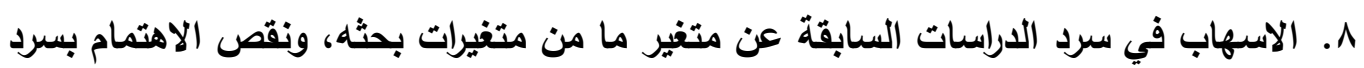

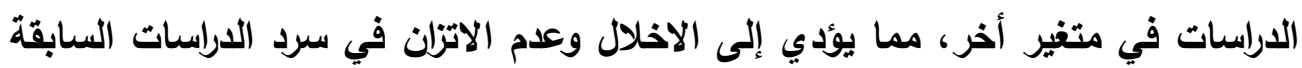
حول متغيراته. 9 ـ عدم الاهتمام بمراجعة الدراسات السابقة في التراث الأجنبي، والاقتصار فقط على الدراسات

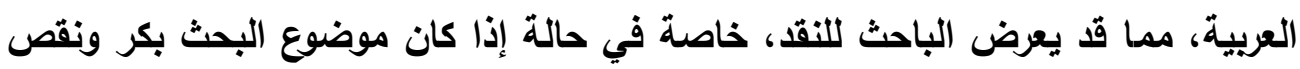
في الاهتمام البحثي في الأدبيات العربية. ـ أ. مراجعة دراسات سابقة غير رصينة منهجيًا. إمراجعة بحوث غير منشورة. 


\section{الحادي عشر : أخطاء في صياغة فروض البحث}

من بين أبرز الأخطاء في صياغة فروض البحث إن وجلت، ما يلائي

ا ـ لا يستند في صياغة فروض بحثه على الدراسات السابقة والإطار النظري.

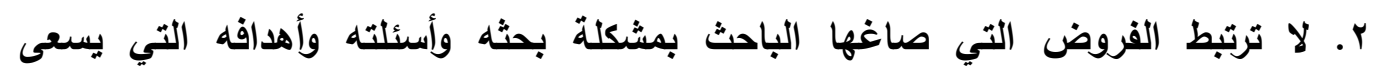

لتحقيقها.

r. لا يصيغ فروض بحثه صياغة مختصرة محددة وواضحة ودقيقة، ويصيغها غير قابلة لاختبارها.

ع. لا يوجه الباحث فروض بحثه البديلة حينما يجب عليه ذلك، في ضوء نتائج البحوث

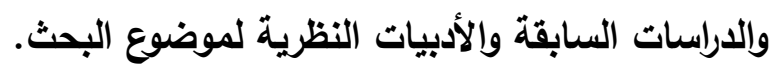

هـ ذكر صيغة للفروض تحت عنوان فروض البحث مختلفة عن الصياغة التي يوردها في فصل النتائج. 7. البعض يقع في خطأ كتابة افتراضات البحث بدلا من فروض البحث، الافتراضات مسلمات لا تحتاج إلى اختبار وتحقق منها مثل الفروض. له.

الثاني عشر : أخطاء تصميه البحث ومنهجيته

بعد صياغة مشكلة البحث بعبارات واضحة، سيُطلب من الباحث إعداد تصميم بحثي.

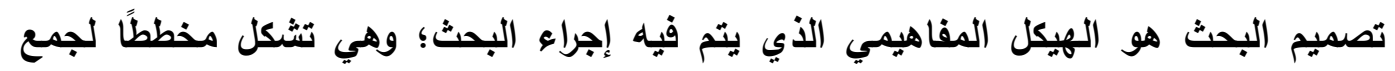
البيانات وقياسها وتحليلها بطريقة تهدف إلى الجمع بين الغرض من البحث والاقتصاد في

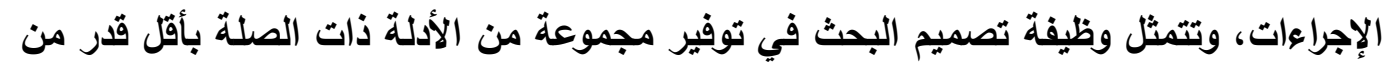
الجها والوقت والمال. وتصميم البحث كإطار عمل مرتبط بمجموعة معينة من الإتتراضات النموذجية التي يستخدمها الباحث لإجراء بحثه مثل الوضعية وما بعدها والبنائية والبراجماتية ونقد النظرية وغيرها (Creswell \& Creswell, 2018). أكد (Allan and Randy 2005) على أنه عند تخطيط تصميم البحث يجب أن يستوفي المعيارين التاليين: أولاً: يجب أن يكون تصميم البحث الذي يختاره الباحث هو الأنسب لتحقيق أهداف البحث. 
ثانياً: يجب أن يكون من الممكن تكرار التصميم المستخدم في البحوث الأخرى التي تكون من نفس طبيعة البحث الحالي.

\section{ومن الأخطاء الثائعة في كتابة تصميج البحث ومنهجيته، ما بلي:}

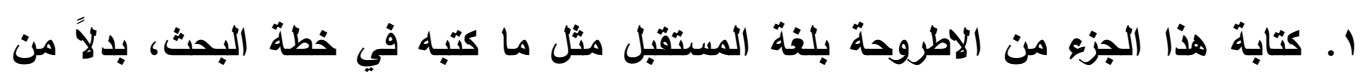

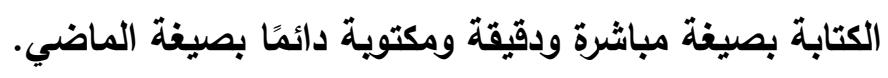

r. لا يحقّ الباحث توقعات القارئ عند قراءته لجزء تصميم البحث في أطروحته، إذ أن القارئ

يتوقع أن الباحث في هذا الجزء يكتب عن تصميم بحثه وخطواته الإجرائية أي منهجه

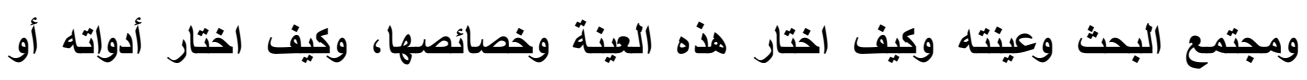

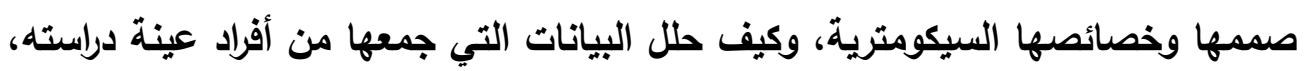

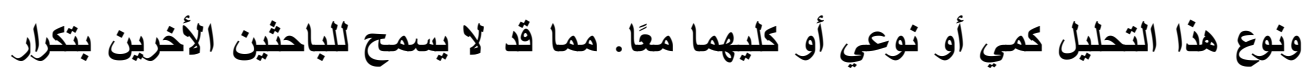
التصميم في بحوث أخرى خاصة في العلوم الاجتماعية. r. ع عم معرفة الباحث بالافتراضات التي يقوم عليها التصميم الذي فئي اختاره للادراسة أو الفلسفة

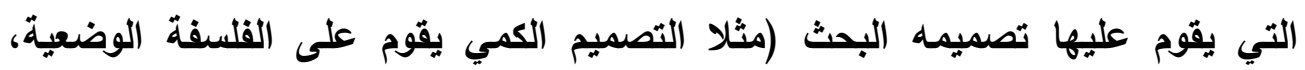

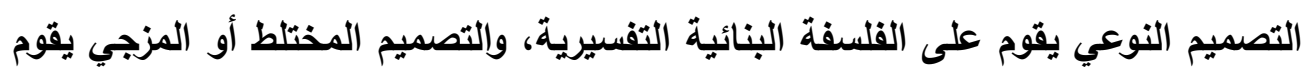

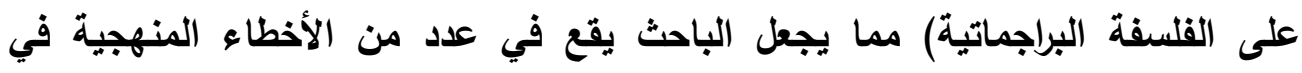

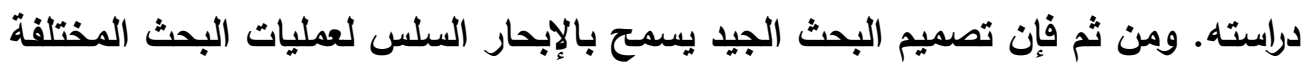

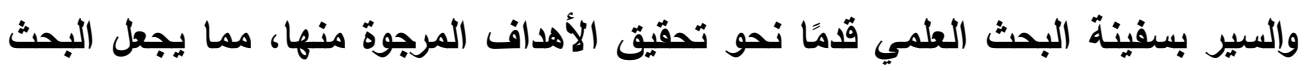

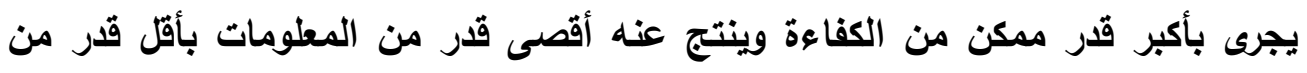
الجها والوقت والمال وهذه هي جودة تصميم البحث والاحترافية في تنفيذه، إذ يشكل تصميم البحث ذلك الأساس الراستخ للصرح الكامل للعمل البحثي.

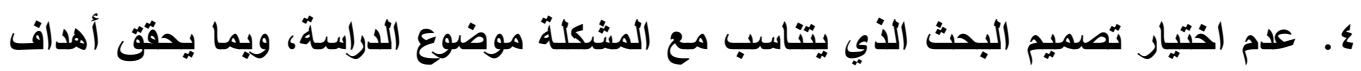

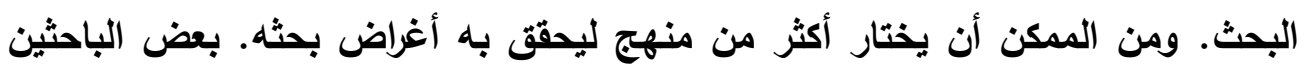

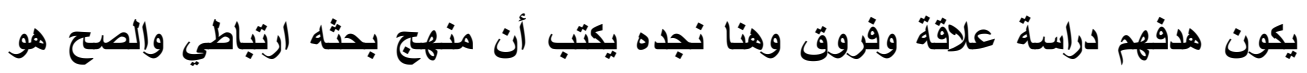

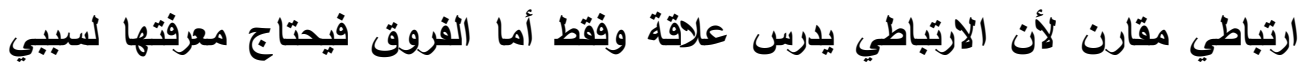

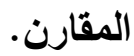
هـ اختيار تصميم بحثي لا يحقى أغراض البحث وأهدافه. 
7. . لا يبرر الباحث للقارئ سبب اختياره لتصميم البحث دون غيره، مما قد يتسبب في ارتباك

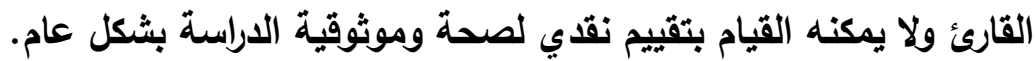
V. عدم الاقتصادية في إجراءات البحث، حيث يستغرق من الباحث وقت وجهر ومال. ^. صياغة تصميم البحث دون أن يجيب الباحث للقارئ عن سؤالين، هما: كيف تم جمع وتوليد بياناته؟ وكيف تم تحليلها؟ مما يجعل القارئ يشعر بالريبة في النتائج التي توصلت إليها الدراسة وأن الباحث قـ تأثر بالمنظور الشخصي والأهواء. 9 ـ عدم الكتابة حول تعريف نوع التصاميم غير المعروفة جيدًا لاى بعض جمهور البحث وإجراءاتها، مثل البحث النوعي أو المختلط، وكذلك عدم تسمية نوع التصميم النوعي أو لو المختلط الذي يستخدمه الباحث في دراسته مثلا التصميم الاثنوجرافي في النوعي، أو التوضيحي التسلسلي في المختلط. الثالث مشر : أخطاي في وصف مجتمع البحث مجتمع البحث يقصد به جميع العناصر أو الوحدات التي تنتمي إلى "مجتمع" البحث وتعمم عليه النتائج التي يتم التوصل إليها؛ ولهذا يجب على الباحث أن يقوم بحصر جميع وحدات

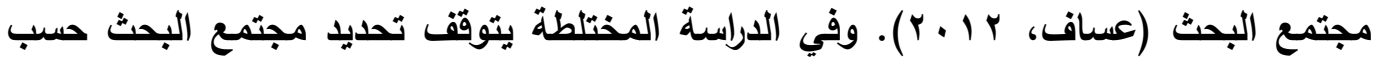
نوع التصميم الأي يختاره الباحث سواء المتقارب أو التوضيحي المتسلسل أو الاستكشافي المتسلسل، لتحديد ما إذا كان مجتمع البحث في المرحلة الكمية هو نفسه في المرحلة النوعية

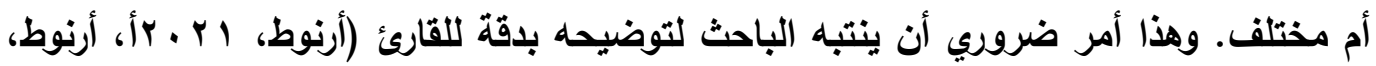

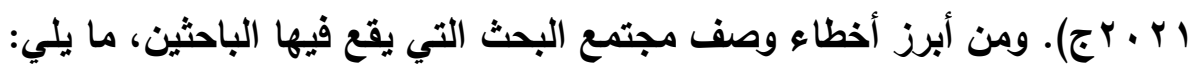
1 ـ عدم الحصول على إحصائية لمجتمع البحث في البحوث الكمية والحلقة الكمية من البحوث المزجية، في حالة توفر ذلك. ليتمكن القارئ من الحكم على أن عينة البحث ممثلة لمجتمع فئه

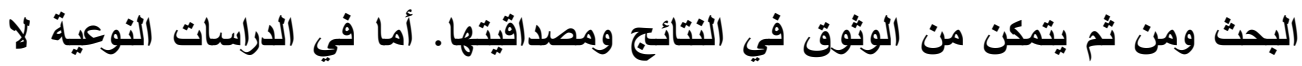
ضرورة لأكر احصائيات لأن الهوف ليس تعميم النتائج. r . عدم مراعاة نوع التصميم المختلط المستخدم مثلاً التوضيحي التسلسلي أو الاستكشافي التسلسلي عند صياغة مجتمع البحث للتحديد ما إذا كان مجتمع البحث في المرحلة الكمية هو نفسه في المرحلة النوعية أو مختلف، وهذا أمر ضروري لابد أن ينتبه إليه الباحثين 
الأين يستخدمون التصاميم المختلطة. وذلك لأن تحديد مجتمع البحث يتوقف على نوع

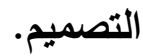

\section{الرابع عشر : أخطاء اختيار عينة الدراسة}

من أبرز الأخطاء التي يقع فيها الباحثين عند اختيار ووصف عينة بحثهم، ما يلي: ا ـ عدم مناسبة طريقة اختيار العينة مع التصميم البحثي الأي تم اختياره. r. عدم توضيح الباحث الطريقة التي اختار بها عينته أو نوع العينة. r. عدم وصف الباحث لعينة دراسته وصف دقيق وشامل، وفي حالة البحوث التجريبية لا يحسب توضب التكافؤ بين المجموعتين التجريبية والضابطة قبل التجربة في المتغير التابع أو المتغيرات الاخيلة (بعض الباحثين يضعون هذا كسؤال وفرض وهذا خطأ شائع لاى الكثير على الرغم

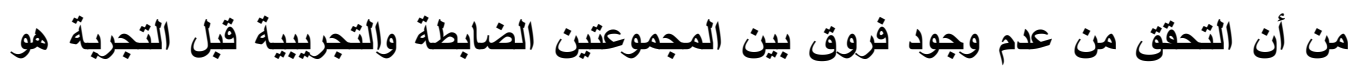
شرط ضروري لإجراء التجرية حتى نتمكن من تفسير ما نحصل عليه من نتائج أنه بسبب المتغير المستقل). ع. عدم تبرير الباحث استخدام العينات القصدية الهادفة في البحوث الكمية التي من المفترض أن تكون عينتها كبيرة ممثلة لمجتمع الأصل وعشوائية فيما عدا البحوث التجريبية عينتها صغيرة وقصدية. ه. خطأ بعض الباحثين في كتابة أن عينة بحثهم عثوائية في البحوث التجريبية، لأن عينتهم قصدية ذات شروط معينة، أما في حالة وجود مجموعتين أو أكثر يكون تعيينهم عشوائي. †. في البحوث النوعية أو المرحلة النوعية من البحوث المختلطة لا يحدد الباحث نوع العيدة العينة

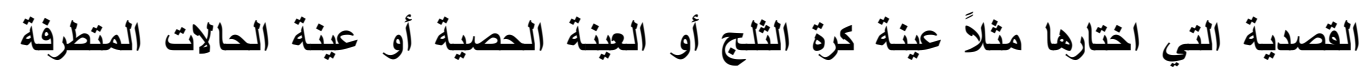
وغيرها.

V. علم مناسبة عدد أفراد العينة مع حجم مجتمع الأصل وذلك في البحوث الكمية أو المرحلة الكمية من البحث المختلط. ^. عدم تحديد نوع التصميم المختلط ومن ثم يقع الباحث أحيانًا بسبب هذا في عدم قدرته على تحديد ما إذا كانت العينة في المرحلة الكمية هي نفسها في المرحلة النوعية أم لا. 
ذكر (Creswell \& Clark, 2018) أن الباحث الذي يستخدم الطرق المختلطة يحتاج

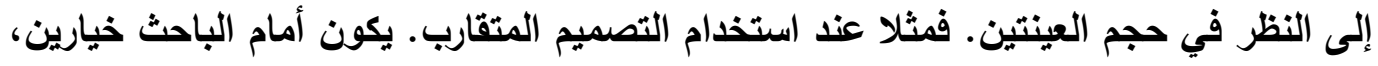
الأول هو أن يكون للعينتين في المرحلة الكمية والنوعية من الداسة أحجام مختلفة، إذ يكون

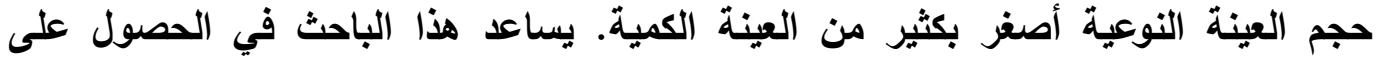
استكثاف نوعي صارم ومتعمق وفحص كمي صارم وقوي للموضوع. يمكن أن يثير هذا التباين في عدد أفراد العينة الكمية والنوعية مسألة كيف يتم التقارب أو المقارنة بين قاعداعتي البيانيات

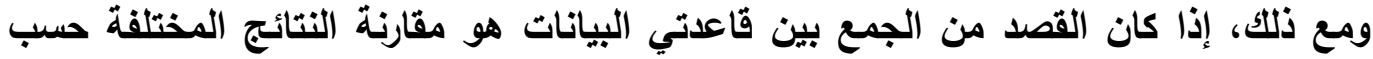

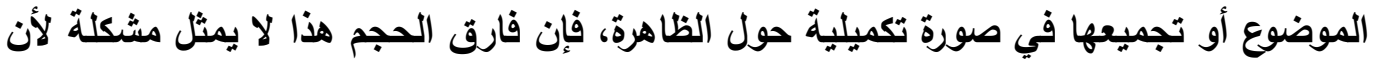
القصد هو الجمع بين الاستتتاجات الكمية والنوعية، إذ يكون الهذف من جمع البيانات الكمية هو التعميم بينما يسعى جمع البيانات النوعية إلى تطوير فهز متعمق من عداد قلئل التيل من الناس.

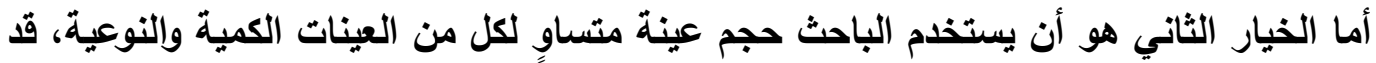

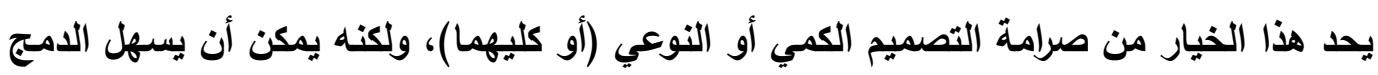
لأن كلا الثكلين من البيانات يتم الحصول عليهما من نفس المشاركين. وأضاف (Creswell \& Creswell, 2018) أن هناك بعض المواقف التي تتطلب حجم عينة كبير لكلا المرحلتين الكمية والنوعية. فعنما يستخدم الباحثون متغير تحويل البيانات للتصميم المتقارب، فمن المهم الحصول على عينتين كبيرتين متساويتين في الحجم وتضمين

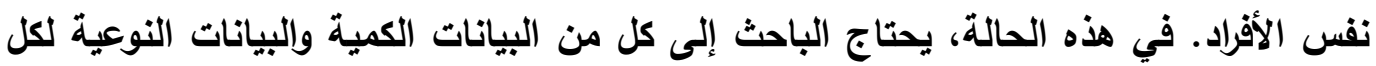
مشارك بحيث يمكن قياس البيانات النوعية وتحليلها كميًا باستخدام المتغيرات المقاسة الأخرى.

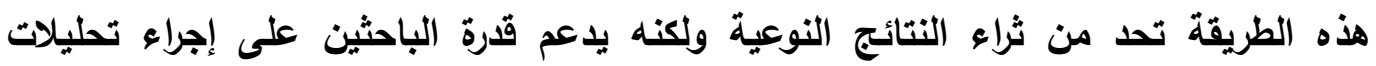

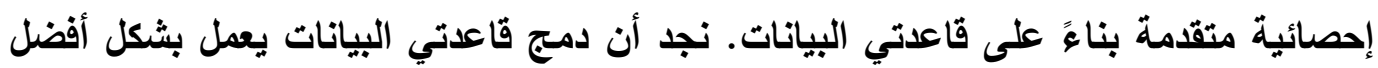
إذا صمم الباحث الاراسة من خلال طرح أسئلة متوازية في كل من جهود جمع البيانات النوعية

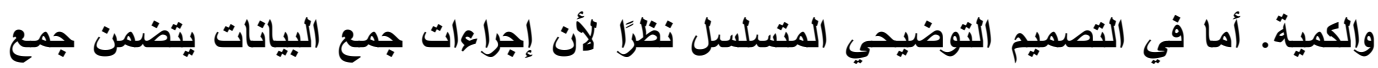
البيانات الكمية وتحليلها واستخذام نتائج هذا التحليل الكمي في متابعة جمع البيانات النوعية؛ فإن يحدث أخذ العينات في هذا التصميم يتم في مرحلتين هما المرحلة الكمية وفي المرحلة النوعية، وقد يكون حجم عينة إحدى المرحلتين أقل من المرحلة الأخرى. ونظرًا لأن التصميم

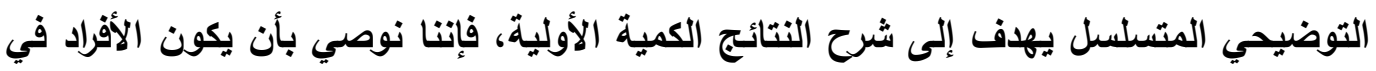


مرحلة المتابعة النوعية مجموعة فرعية من الأفراد الذين شاركوا في جمع البيانات الكمية، لأن الهذف من هذا التصميم هو استخدام البيانات النوعية لتقديم مزيد من التفاصيل حول النتائج الكمية، والأفراد الأكثر ملاعمة للقيام بذلك هم الأين ساهموا في مجموعة البيانات الكمية.

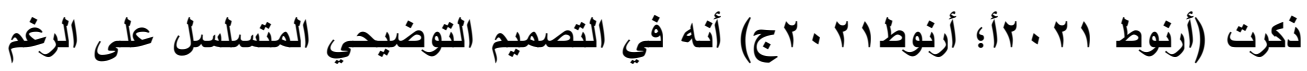

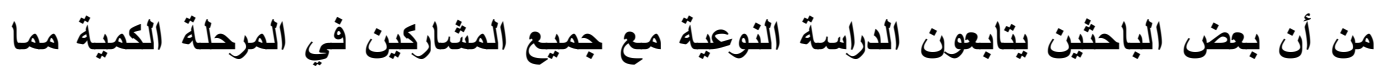
يؤدي إلى أحجام عينات متساوية، فإنتا نوصي بأن يتم جمع البيانات النوعية من عينة أصغر

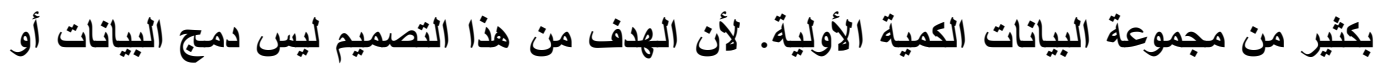
مقارنتها كما في التصميم المتقارب، لذا فإن وجود أحجام غير متساوية للمشاركين في الدراسة لإنة الكمية والتوعية ليس مشكلة في التصميمات المتسلسلة. على عكس التصميم التوضيحي المتسلسل، فإن الأفراد الذين يشاركون في المتابعة الكمية للتصميم الاستكشافي المتسلسل ليسوا

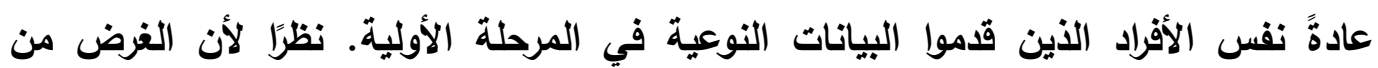
المرحلة الكمية هو التعميم الموضوعي للنتائج على مجتمع البحث، يتم استخدام مشاركين

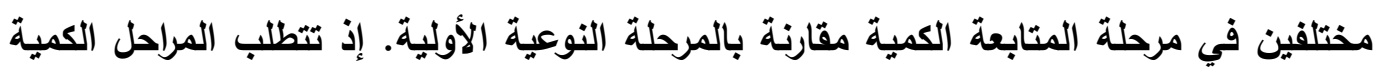
أحجام عينات كبيرة بحيث يمكن للباحث إجراء اختبارات إحصائية وريما تقديم أدلة حول التعميم

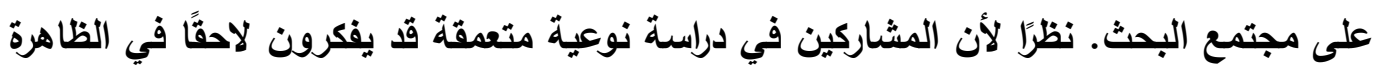
بشكل مختلف، فمن المفضل أيضًا بشكل عام اختبار المواد الكمية مع مشاركين آخرين. الخامس عشر : أخطاء اختياروصياغة أدوات البحث في هذا الجزء من المخطوطة البحثية يقع الباحثين في العديد من الأخطاء، والتي من أكثرها شيوعًا ما يلي:

1. إعداد أدوات جمع بيانات دون الحاجة إليها، رغم توفر أدوات أعدها باحثين أخرين رصينة وتتوفر فيها الخصائص السيكومترية الجيدة وتتناسب مع خصائص عينة البحث وتحقى لإنق أغراض البحث وأهدافه، إلا أن بعض الباحثين يقررون إعداد أدوات اعثقادًا منهم بأن ذلك

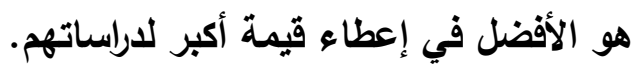
r. اختيار وتطبيق أدوات غير رصينة ذات مؤشرات صدق وثبات ضعيفة. 
r. اختيار وتطبيق أدوات لا تتاسب أهداف البحث، ولا خصائص عينة البحث مثلا يستخدم الباحث أداة أعدت للمراهقين ويطبقها على عينته من الأطفال. ـ. تطبيق الأدوات التي تم اختيارها ومعدة من باحثين سابقين دون التحقى من خصائصها السيكومترية من صدق وثبات، ويالأخص عند تطبيق الباحث لاراسة استطلاعية في مرحلة إعداد الخطة. ه. عدم احترام الملكية الفكرية للباحثين الأخرين الذين بذلوا جهودًا مضنية في إعدادها للبيئة العربية. فنجد أخذ عبارات من مقاييس ونسبها لأنفسهم أو ابعاد أو ريما المقياس بأكمله

ونسبه لنفسه.

4. عدم تحكيم أدوات البحث، أو تحكيمها من غير المختصين والتعديل في ضوء توجيهاتهم ونسب الاتفاق فيما بينهم. V. نقص في وصف الأداة مثل عدم توضيح الهذف الذي تقيسه الأداة ولمن صممت وطريقة الإجابة ومفتاح التصحيح. ^. عدم توضيح خطوات إعداد الأداة للقارئ، والصورة المبائية والصورة النهائية.

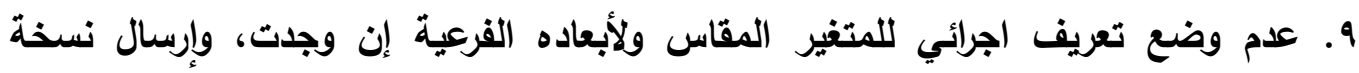
التحكيم دون هذه التعريفات الإجرائية ومن ثم لا يتمكن المحكم من تقرير ما إذا كاتت وصعاده العبارات تتنمي إلى البعد أو لا. • 1 . أخطاء قياسية في صياغة بنود الأدوات. مثل بلءء صيغة العبارة بالنفي، أو صياغة عبارة غامضة وتحتمل أكثر من معنى وتتضمن أكثر من جاتب لقياسه.

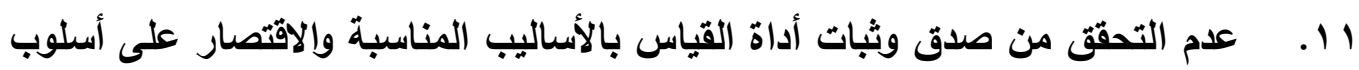
واحد فقط. r 1. كتابة ثبات الأداة قبل صدقها. والصح أنه يكتب الصدق قبل الثبات لأن الأداة الصادقة ثابتة بالضرورة وليس العكس.

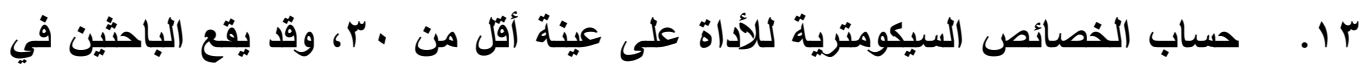
خطأ اختيار عينة الخصائص السيكومترية من نفس عينة الاراسة وليس من نفس مجتمع البحث. 
؛ 1 . الاقتصار على صدق المحكمين دون التحقق من أنواع أخرى من الصدق الاحصائي، فصدق المحكمين غير كاف وحده.

ه ا. الاعتماد على الصدق الذاتي أو صدق المقارنة الطرفية وهو أضعف أنواع الصدق.

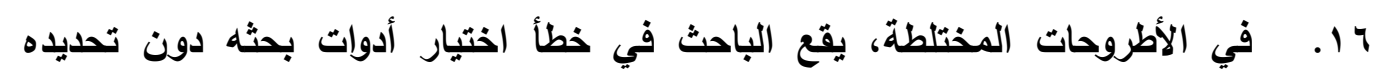

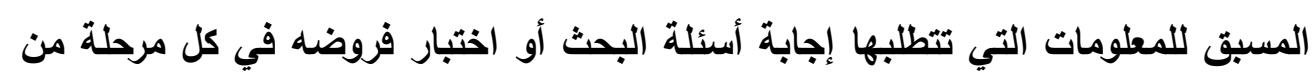

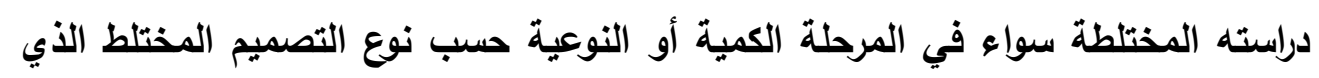
اختاره سواء متقارب أو توضيحي متسلسل أو استكشافي متسلسل.

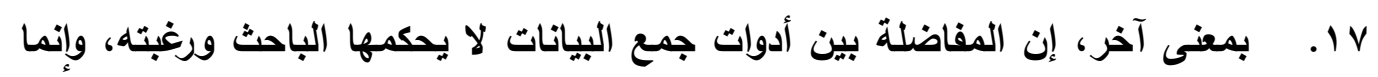
تتحدد بعدة عوامل منها طبيعة الظاهرة المحورية، مصادر المعلومات، تصميم البحث

\section{المتبع.}

السـادس عشر : أخطاي اختيار أساليب تحليل البيانات

من بين أكثر الأخطاء التي يقع فيها الباحثين في إعداد وصياغة اختيار أساليب تحليل

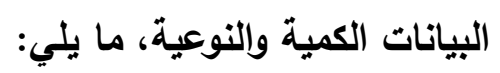

1. عدم اختبار اعتدالية توزيع درجات أفراد عينة البحث في البحوث الكمية قبل اختيار الأساليب الإحصائية للتحقق من فروض البحث أو الإجابة عن أسئلته. حتى لو كان حجم البه

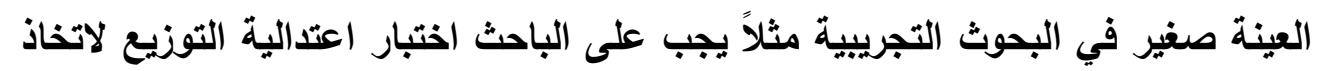

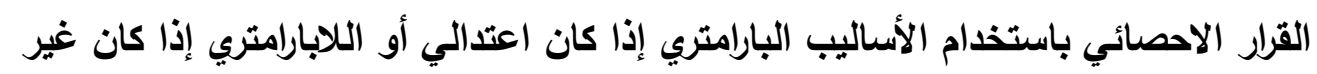

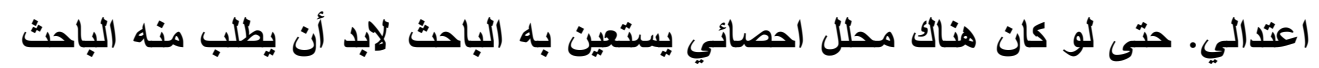

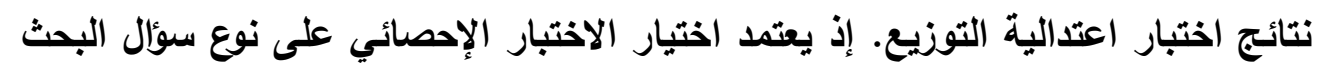

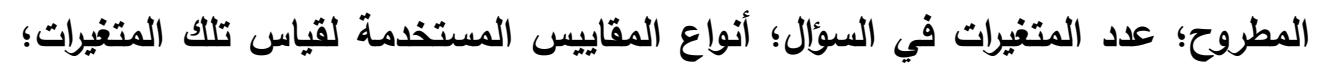
وما إذا كانت درجات المتغيرات موزعة بشكل اعتدالي أو غير اعتدالي. r . عدم اختيار أساليب التحليل التي تتناسب مع تصميم البحث ولتحقيق أهدافه. r. عدم مراعاة نوع تصميم البحث المختلط عند تحليل البيانات. مثلا هل يتم دمج القاعلتين الكمية والنوعية معًا في التحليل، أم سيتم تحليل كل منها منفصلة، وهل سيكون جمع نداء وتحليل البيانات الكمية أولا أم النوعيةٌ وإذا لم يحدد الباحث منذ البداية نوع تصميمه 
المختلط فإن هذا سيجطله يقع في الكثير من الأخطاء في خطوات البحث ومنها خطوة جمع وتحليل البيانات.

\section{السابع عشر : أخطاء في صياغة نتائج البحث ومناقشتها وتفسيرها}

يقع بعض الباحثين في أخطاء عند صياغة نتائج بحوثهم الكمية وإلنوعية والمزجية، من بين ابرز هذه الأخطاء شيوعًا، والتي تسبب الترهل البحثي للمشروع أو المخطوطة، ما يلي: 1. البدء في عرض النتائج في البحوث الكمية دون التوضيح لجمهور البحث عن نتائج اختبار اعتدالية التوزيع والتي في ضوئها تم اختيار الأساليب الإحصائية للإجابة عن

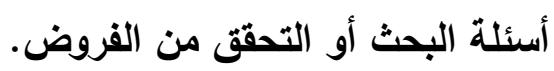
r. ع عم تسلسل عرض النتائج بوضوح ويصورة منطقية تتناسب مع أهداف البحث وأسئلته أو فروضه.

r. نسيان بعض الباحثين الإجابة عن بعض الأسئلة أو التحقق من بعض فروض بحثه.

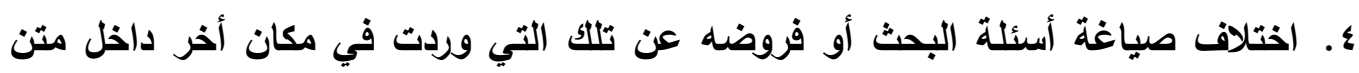
البحث تحت عنوان أسئلة البحث وفروض البحث. وهذا قد يكون لأن الاحصائي قام بتعديل صياغة بعض منها لتصحيحها والباحث لم ينتبه لألك مما تسبب في وقوعه في خطأ اختلاف صياغتها في هذا الفصل عن صياغتها في الفصول الأخرى. ه. خلط بعض الباحثين بين مفهوم مناقشة النتائج وتفسير النتائج. ففي مناقشة النتائج يعلق على النتائج الواردة في الجداول أو الأثكال التي يجيب بها عن الأسئلة أو يتحقى من الفروض. مثلا توجد علاقة ارتباطية دالة احصائيا أو توجد فروق دالة أو الفروق لصالح الأكور أو مجموعة ما وهكذا. أما تفسير النتائج يعني تفسير ما توصل إليه من نتائج في ضوء الإطار النظري الأي عرضه في الفصل الخاص بأدبيات البحث وتبنى منه نظرية معينة يفسر بها بياناته ويقع الباحث في هذا الخطأ بسبب انه لم يتبنى نظرية أثناء عرضه لكأدبيات النظرية. 1. اعتماد الباحث على التفسير الاتي في تفسير نتائج بحثه، مما قد يوقعه في مشاكل مثل القول بأشياء وكأنها حقائق رغم عدم وجود سند علمي أو دليل نظري ولا دراسات سابقة تشير إلى ذلك. 
V. لا يوضح بعض الباحثين الاتفاق أو الاختلاف بين نتائج بحثه والدراسات السابقة خاصة

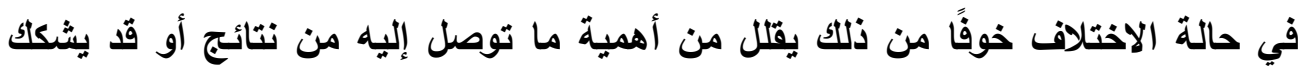

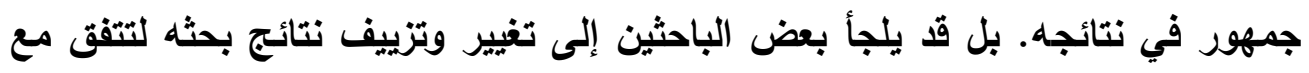

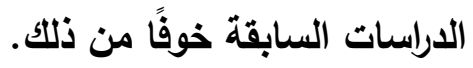

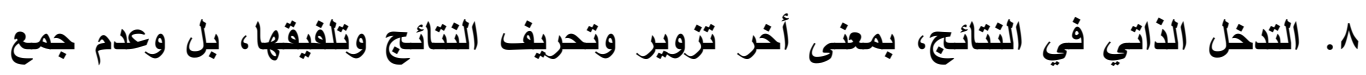
بيانات وتحليلها من الأساس، إذ يجلس الباحث على مكتبه ويكتب ما يملى عليه من أرقام

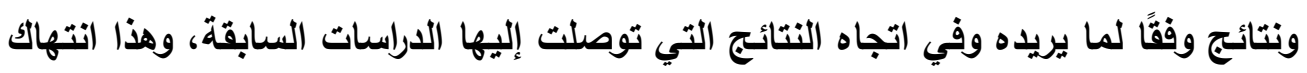

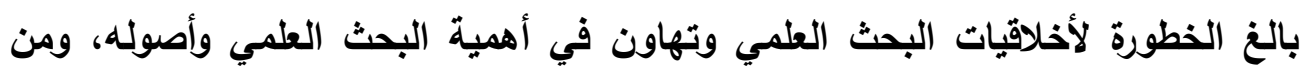

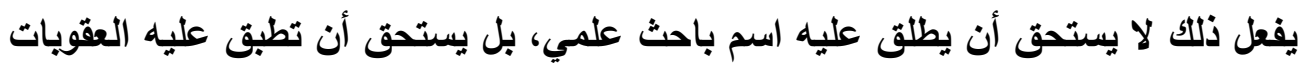
وفقًا لوائح مجالس التأديب بالجامعات ومراكز البحوث.

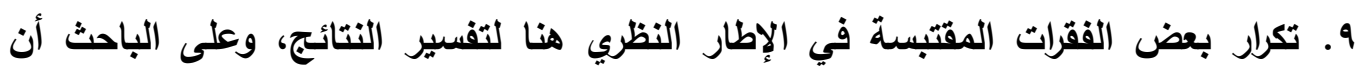
يدقق في ذلك تحقيقًا لمبدأ الاقتصادية في العلم والدقة في الكتابة العلمية الواعية.

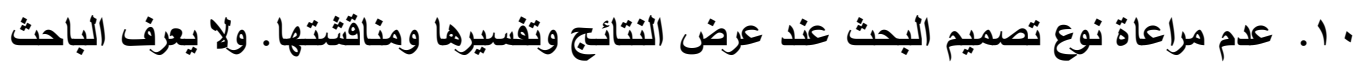

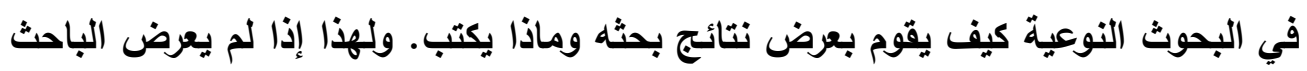

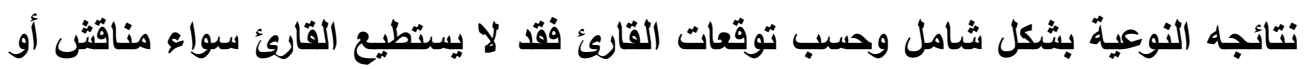

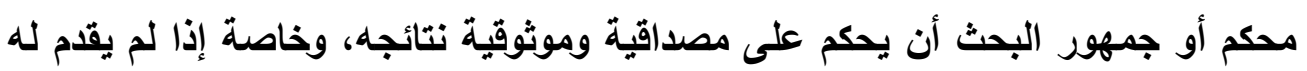
الاستراتيجيات التي بها حقق المصداقية والموثوقية في نتائج بحثه. 11 ا. عدم عرض نتائج البحث في ضوء نوع تصميم البحث المختلط في الاطروحات المختلطة. لأن حسب نوع التصميم سيعرض نتائجه الكمية أولا أو النوعية أو العكس. وكنلك عند التهات

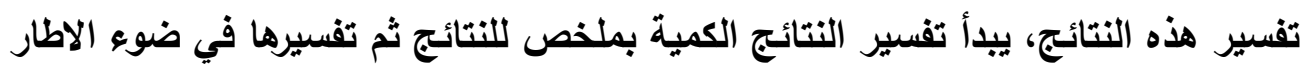

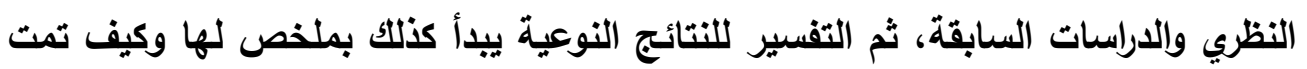

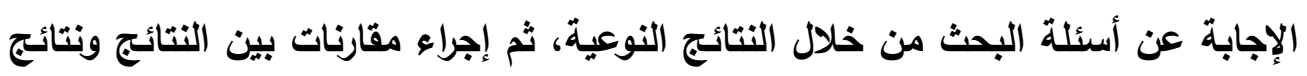

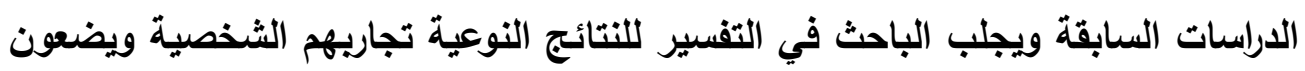

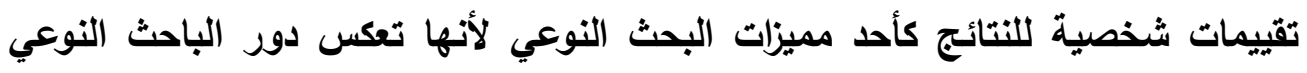
لأنه لا يمكن الفصل بين البحث وتفسيراته عن انعكاسية الباحث ووجهات نظره وخصائصه الثخصية عكس الباحثون الكميون. 
r ا. . عرض نتائج انشائية كثيرة لا داعي لها، وليس لها استتادًا علميًا في البحث. r 1. علدم عرض الباحث لإجراءات ضمان صحة النتائج وتفسيرها في البحث، خاصة في البحوث النوعية والمختلطة في كلا مرحلتيها الكمية وإلنوعية. ـ 1 . عدم ذكر الباحث جوانب قصور بحثه والتوجهات المستقبلية لجمهور البحث. الثامن عشر : أخطاي صياغة توصيات البحث في هذا الجزء من المشروع أو المخطوطة البحثية، يقع الباحثين في عدد من الأخطاء، منها ما يلي: ا ـ ـ ذكر توصيات لا ترتبط بنتائج البحث. r. اعتقاد الباحث أن ذكر عدد كبير من التوصيات هو الأفضل دون مراعاة ارتباطها بما

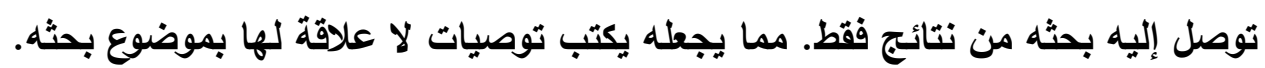
r. ذكر توصيات بحث تم تتفيذها من قبل. صياغة توصيات غير إجرائية لا يمكن تنفيذها بل ويستحيل تنفيذها بالواقع.

\section{التاسع عشر : أخطاي صياغة البحوث المقتز حة}

في هذا الجزء من المشروع أو المخطوطة البحثية، يقع الباحثين في عدد من الأخطاء والتي تتسبب ليس فقط في ارتباك القراء، بل وريما تتسبب في تدهور أداء الباحثين غيرهم ممن يستعينون بمقترحاتهم البحثية في اختيار مشكلة لمشروعهم البحثي، ومنها ما يلي:

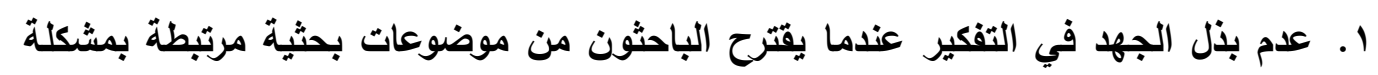
بحثهم لغيرهم من الباحثين المهتمين بدراسة نفس المشكلة موضوع بحثهم.

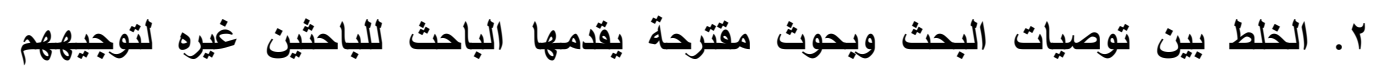
للجوانب الأخرى من مشكلة بحثه التي لازالت تحتاج دراسة أو استخدام منهجيات بحثية أخرى وما يساعد الباحث في كتابة ذلك هو وعيه بجوانب قصور بحثة الحالي. r. تقديم مقترحات بحثية تم دراستها من قبل.

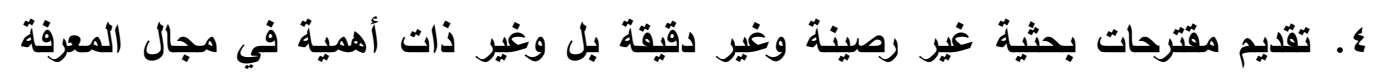

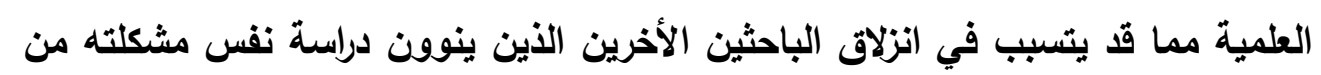

$$
\text { جواتب أخرى أو بمنهجيات أخرى في الأخطاء. }
$$


هـ تقديم مقترحات بحثية غير قابلة للبحث ماديًا وعلميًا.

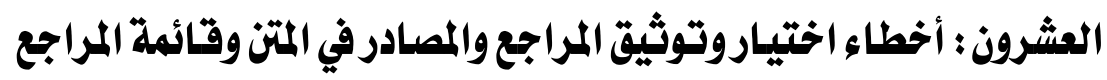

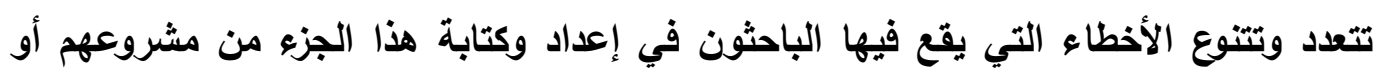

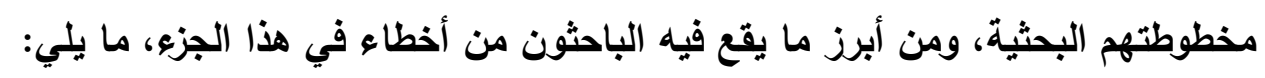

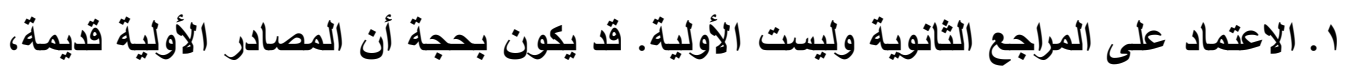

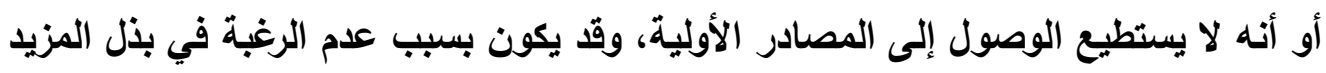
من الجها في البحث عن المراجع. r. عام كفاية المراجع التي رجع اليها الباحث، وعام مسحه الجيد لجميع ما كتب من أدبيات

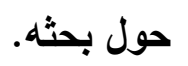
r. عام كتابة الداسات السابقة ضمن مراجع البحث.

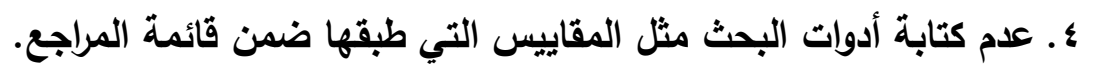
ه. و عدم كتابة البرامج المستخدمة في تحليل البيانات في قائمة المراجع.

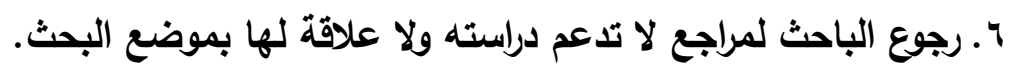

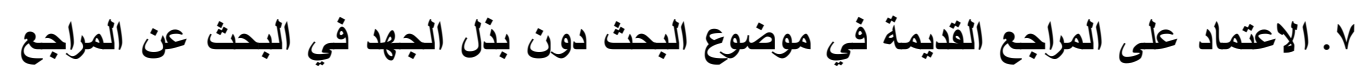
الحديثة.

1. الاعتماد على مصادر ومواقع بالإنترنت غير موثوق بها.

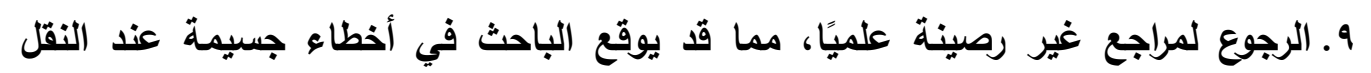

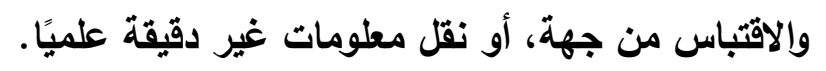

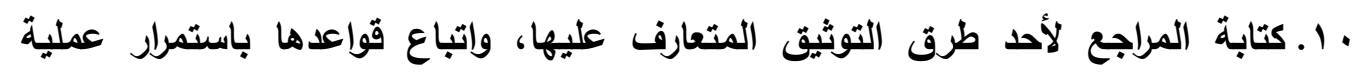

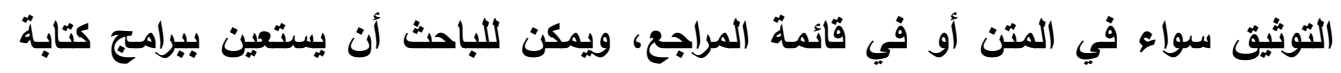

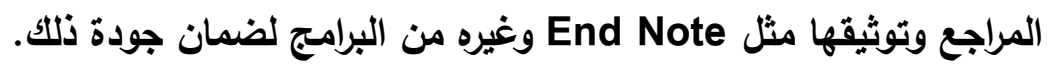

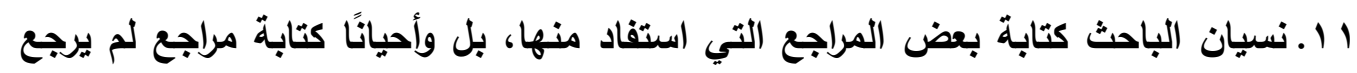
إليها. ولضمان ذلك عليه أن يستخدم برامج كتابة المراجع وتوثيقها. 


\section{الحادي والعشرون : أخطاء صياغة مستخلص البحث باللفتين العربية والأجنبية}

يكثر بين الباحثين العرب أخطاء كثيرة عند صياغة مستخلص بحثهم سواء باللغة العربية

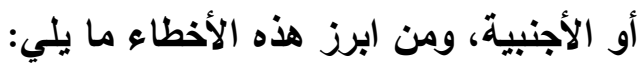

1. الخلط بين ملخص البحث ومستخلص البحث، مما يجعل بعض الباحثين يضعون عنوان خطأ في قسم مستخلص البحث، يكتبون ملذص البحث بلاًا من المستخلص. ومن

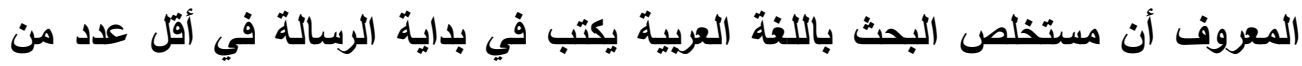

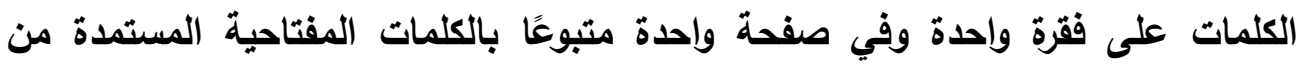
موضوع البحث وليس من العنوان فقط كما يعتقد بعض الباحثين. أما ملذص البحث يكتب

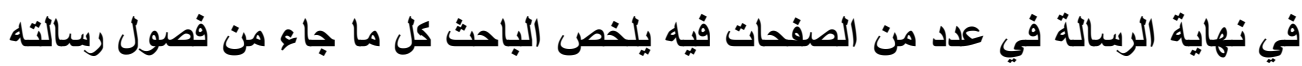
بشكل مجمل.

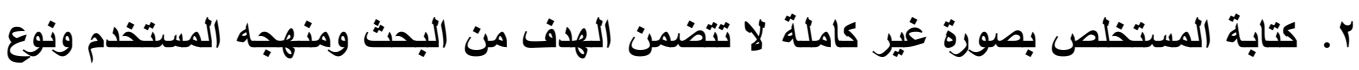
التصميم البحثي، وعينته وأدواته وأبرز نتائجه ويعض من توصياته المختصرة جدًا. فقد يقل

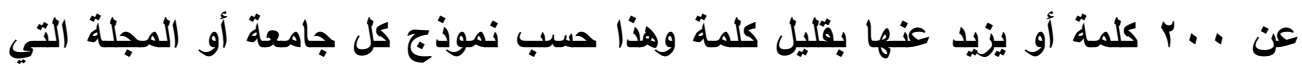
ينشر فيها البحث. r. أخطاء ترجمة المستخلص باللغة العربية إلى اللغة الأجنبية لعدم اعتماد بعض الباحثين على أنفسهر في الترجمة واعتمادهم على مترجمين غير متخصصين، ومن ثم يترجمه ترجمة حرفية. أو اعتماد الباحث على نفسه مما يوقعه في أخطاء القواعد، ويجعل المستخلص غير قابل للقراءة من جمهور البحث.

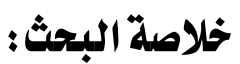

إن هذا البحث يعد دراسة نظرية تناول موضوع الرشاقة والبدانة في إعداد وصياغة

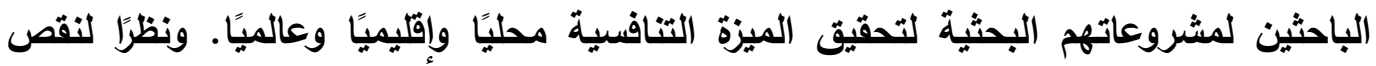

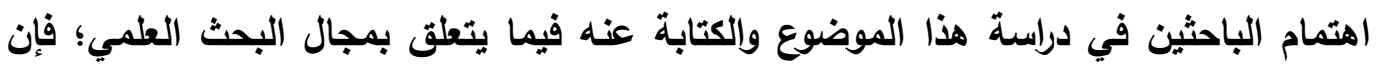

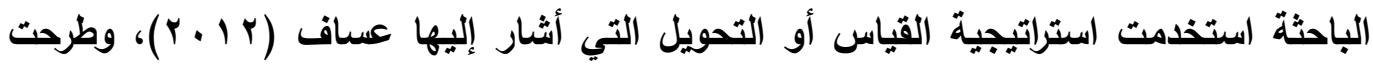
أدبيات نظرية حول مفهوم الرشاقة البحثية والبدانة البحثية في ضوء البراديجم البحثي الذي الذي

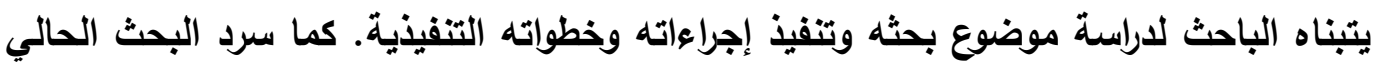


مكونات الأطروحة البحثية، وحدد أبرز الأخطاء الثائعة التي يقع فيها الباحثين عند إعدادهم لمشروعاتهم أو أطروحاتهم العلمية، لتنمية وعي الباحثين بها وليتمكنوا من اكتشاف مثل هذه اله الأخطاء في عملهم البحثي من خلال استراتيجية التقويم الأتي، وأيضًا اكتثافها في أعمال غيرهم بهدف تجنبها عند الشروع في الكتابة وانتقاء الأدبيات النظرية من أطر ومفاهيم ودراسات رصينة مما له صلة بموضوع بحثهم واستبعاد غيرها، وكذلك ليبدي الباحث اتجاه إيجابي نحو إتقان صياغة المشروع أو الأطروحة البحثية بما يحقق لهم الميزة التنافسية ولجامعاتهم أيضًا.

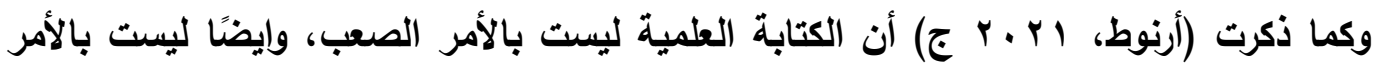
السهل الأي يتهاون به بعض الباحثين. ولابد للباحث أن يكتب مخطوطته البحثية في ضوء

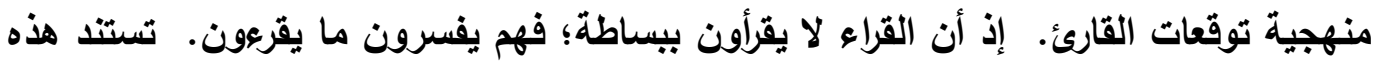
المنهجية لتوقعات القارئ إلى الاعتراف بأن القراء يتخذون العديد من قراراتهم التفسيرية الأكثر أهمية حول جوهر ما يقرؤونه بناءً على القرائن التي يتلقونها من هيكل النص المقروء. إذ يتم

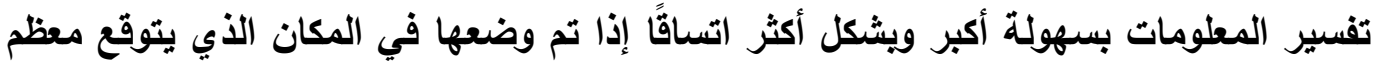
القراء العثور عليه فيه. إذ لا تؤثر احتياجات وتوقعات القراء هذه على تفسير الجداول والرسوم التوضيحية فحسب، بل تؤثر أيضًا على تفسير النص نفسه. إذ لاى القراء توقعات ثابتة نسبيًا حول المكان الأي سيواجهون فيه عناصر معينة من جوهره في بنية نص المخطوطة البحثية. ومن ثم إذا تمكن الكتاب عامة والباحثين خاصة من إدراك هذه المواقع بوعي، فيمكنهم التحكم بشكل أفضل في درجات الاعتراف والتركيز الذي سيعطيه القارئ لمختلف المعلومات التي يتم تقديمها. ويدرك الكتاب الجيدون والباحثون المتميزون بشكل بليهي هذه التوقعات. نستخلص مما سبق، أنه إذا تم انتهاك هذه التوقعات في هيكل المخطوطة البحثية باستمرار، سيجعل المشروع أو الأطروحة البحثية مترهلة ضعيفة البناء مما يضطر القراء إلى هئ فئه تحويل طاقاتهم من فهم محتوى المقطع إلى تفكيك بنيته. ومع زيادة تعقيد السياق بشكل معتدل، تزداد احتمالية سوء التفسير أو عدم التفسير بشكل كبير، فيترتب عليه عدم الوثئق بنتائج

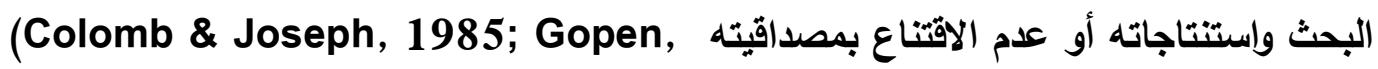

.2018)

إذا التزم الباحثين بنموذج الرسالة سواء الماجستير أو الدكتوراه في جامعتهم، لا شك أن هذا يتيح له إلى حد ما الكتابة في ضوء منهجية توقعات القراء. وكذلك إعداده العلمي الرصين 
في مرحلة المنهجية حول كيف يؤثر براديجم البحث أو الفلسفة التي يقوم عليها كل تصميم

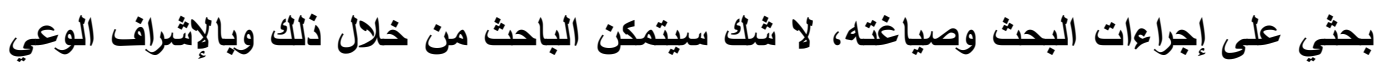

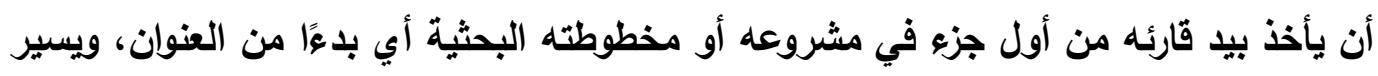

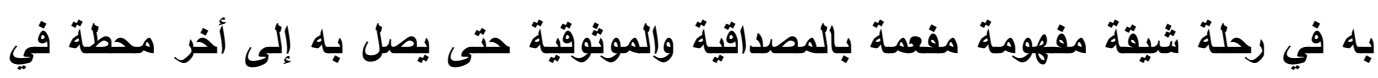

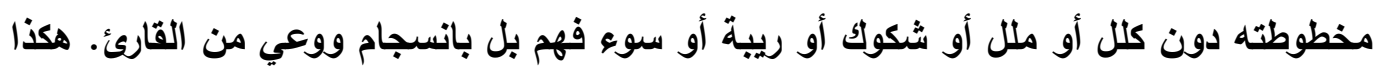
تتحقق الرشاقة والجودة في مخطوطاتنا البحثية ونسهم في نثر المعرفة العلمية الرصينة. أما

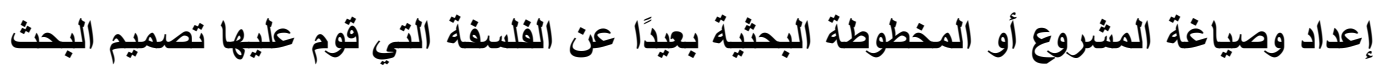

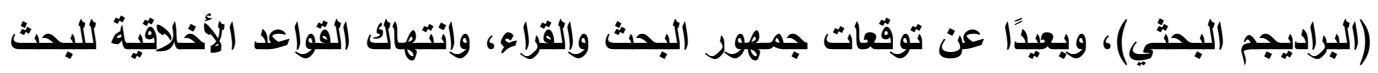

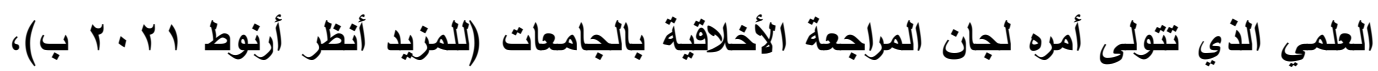

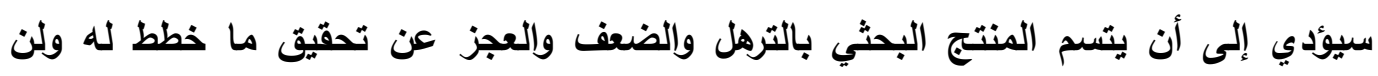

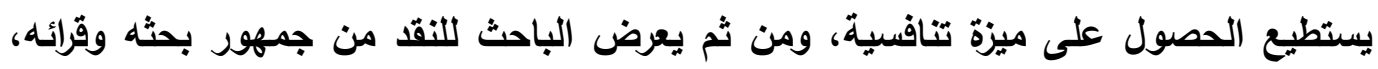

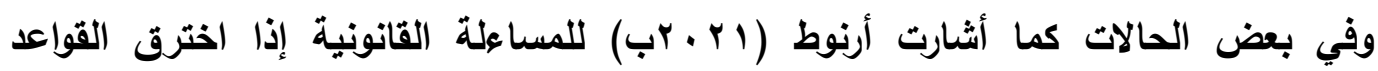
الأخلاقية في سلوكه البحثي أو عدم احترام الملكية الفكرية للأخرين، وتضارب المانداب المصالح.

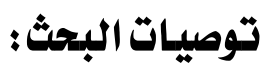
1. تدريب الباحثين على الكتابة في ضوي البراديجم البحثي ومنهجية توقعات القارئ. r. r. تدريب الباحثين على استراتيجيات الكتابة العلمية الواضحة والدقيقة. r. عقد ورش عمل للباحثين والمرشدين الأكاديميين والمشرفين العلميين بالجامعات حول

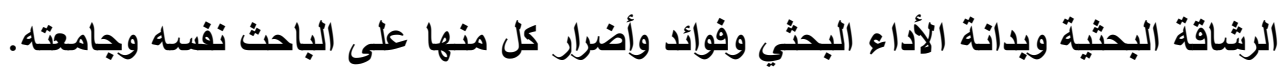

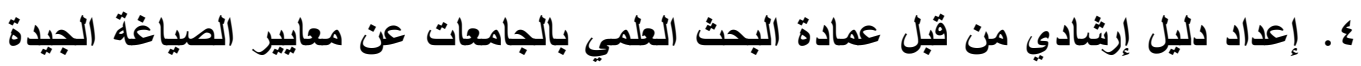

\section{للمشروع أو الأطروحة البحثية الجيدة.}

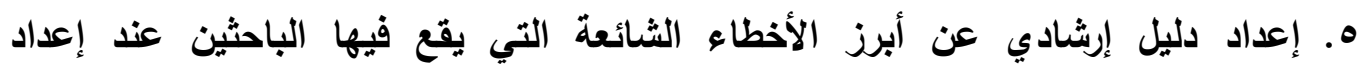

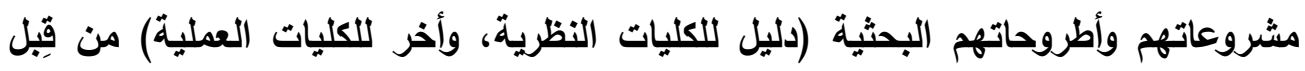

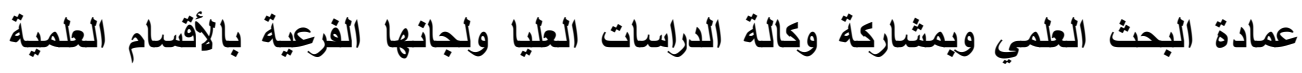
بالكليات، لتوعية الباحثين بها واستبصارها وأخذ الحيطة منها لتجنبها وعدم الوقوع فيها. 
1. تفعيل دور لجان المراجعة الأخلاقية بالجامعات في مراقبة وضبط أداء الباحثين فيها لتحقيق الميزة التنافسية.

V. إنثاء حاضنات للموهوبين بحثيًا من طلبة الدارسات العليا في مرحلتي الماجستير

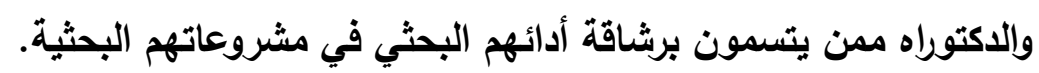

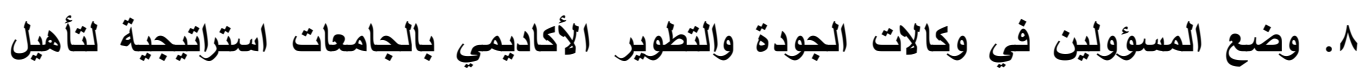
البحث العلمي فيها وفق المعايير الدولية.

قصور البحث والتوجهات المستقبلية: البحث الحالي يعد دراسة نظرية لموضوع جديد في طرحه هام في دراسته؛ هو رشاقة الأداء البحثي وخصائصه ومتطلباته في ضوء البراديجم البحثي ومنهجية توقعات القارئ. كما تناول

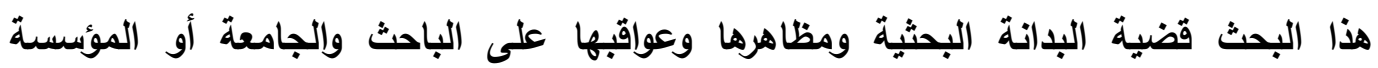
المانحة للارجة العمية أو المنحة الدراسية. من نواحي القصور في البحث الحالي كونه لئه دراسية

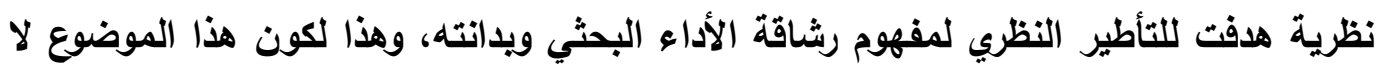

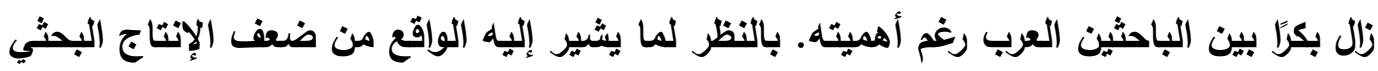

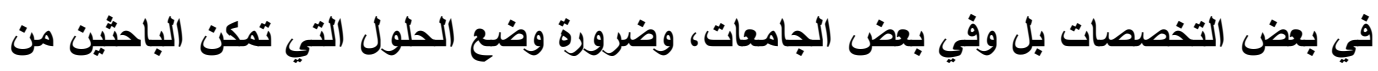
تطوير وتجويد أدائهم، والحاجة الماسة لإتاحة الفرصة أمام الباحثين والجامعات والمراكز البحثية

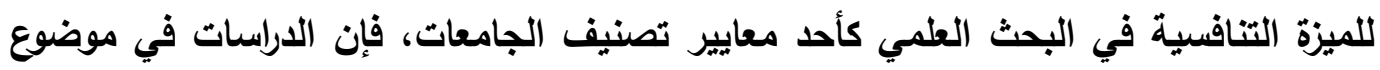
رشاقة الأداء البحثي يمكن أن توجه مستقبلاً نحو دراسته كميًا وإعداد استبانات ومقاييس

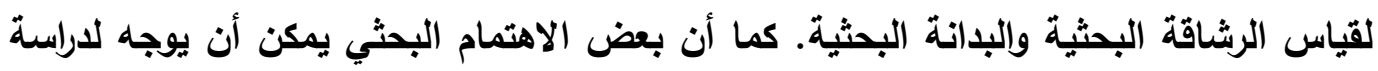

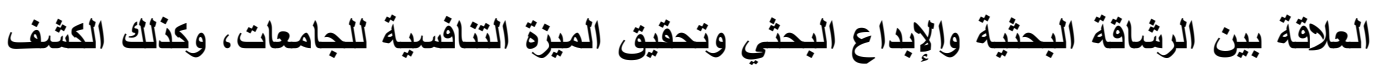
عن دور القيادة الرشيقة في تحفيز أعضاء هيئة التدريس نحو رشاقة أدائهم البحثي. لازال البال

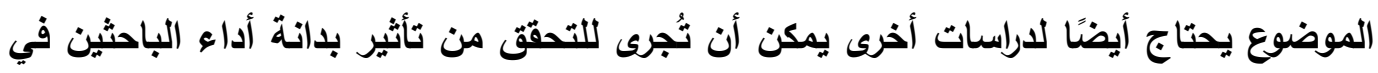

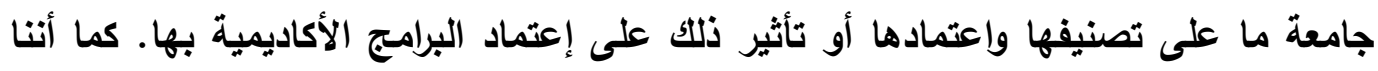
بحاجة لاراسات نوعية حول هذه الموضوعات للتعمق في فهمها وتفسيرها وخاصة قضية التهاية أسباب

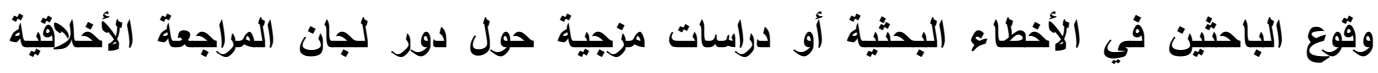

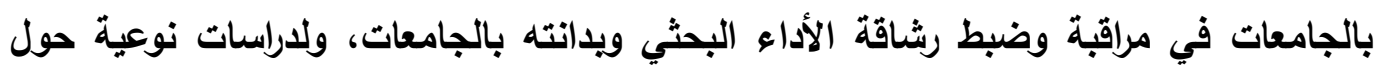



أداء الباحثين في إعداد مشروعاتهم البحثية ...

سمات شخصية الباحثين ذوي الأداء الرشيق والبدين في مشروعاتهم البحثية. فضلاً عن الحاجة لإجراء دراسات بينية يشترك فيها عدد من الباحثين من تخصصات متنوعة لإثراء ما يتوصل إليه

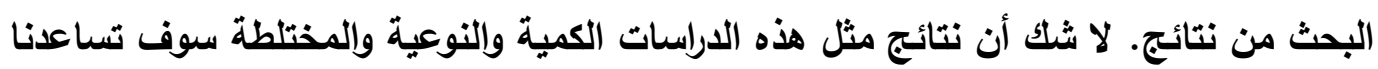

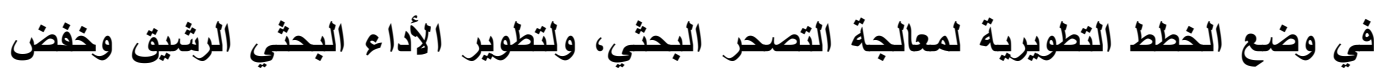

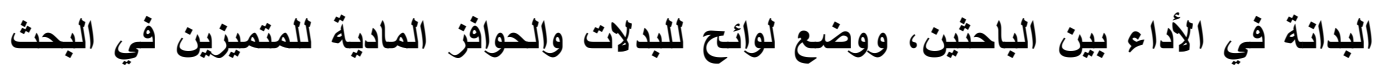
العلمي. 


\section{المراجع}

\section{أولاً : المراجع العربية:}

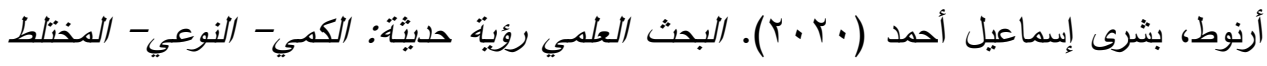

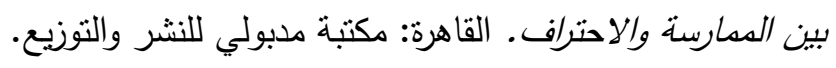

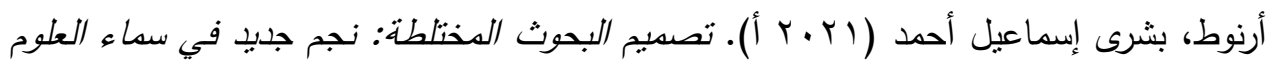

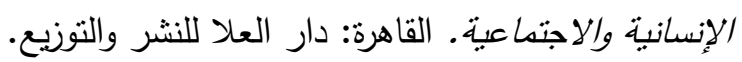

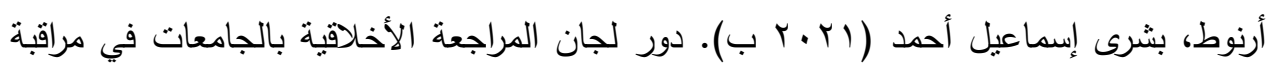

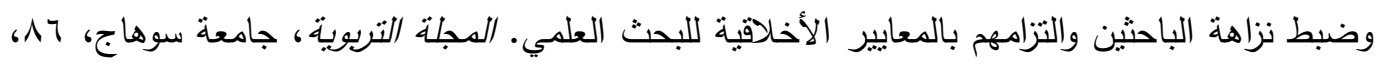
.r. -

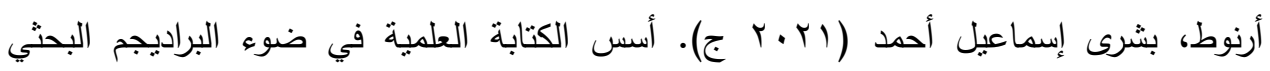

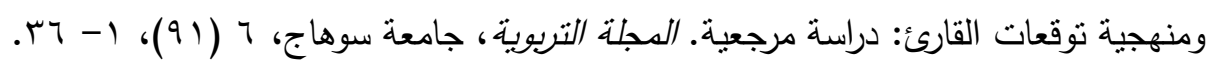

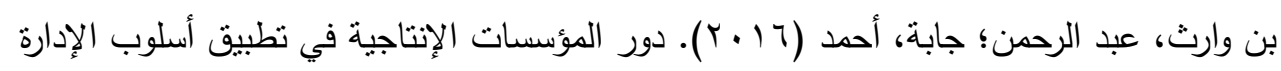

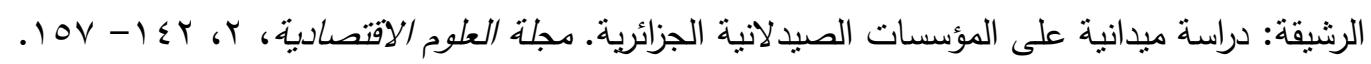

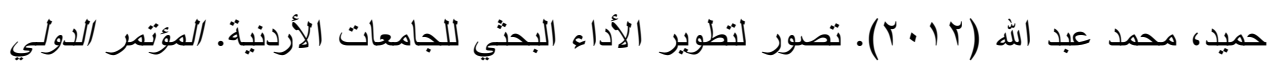

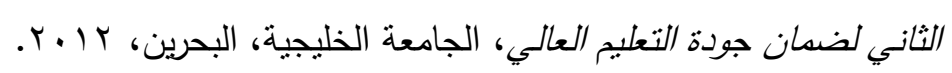

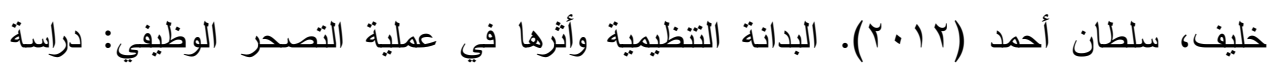
استطلاعية لأراء عينة من العاملين في المعهد التقني الموصل. مجلة دراسات إدرية، جامعة البصرة،

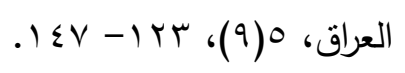

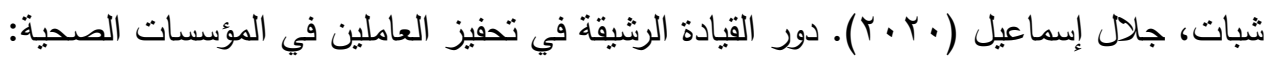
دراسة حالة- اتحاد لجان العمل الصحي في قطاع غزة. مجلة جامعة القدس الكفتوحة للبحوث الإدارية

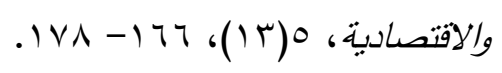

الصديقي، سعيد (10 ( ب). موقع الجامعات العربية في التصنيفات الدولية للجامعات: قراءة نقدية.

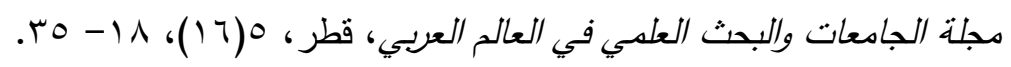

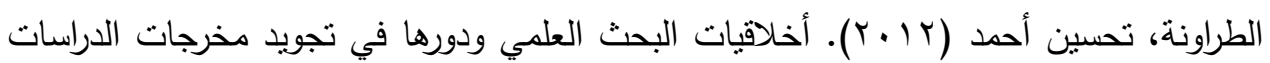

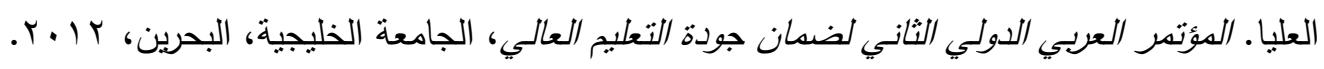

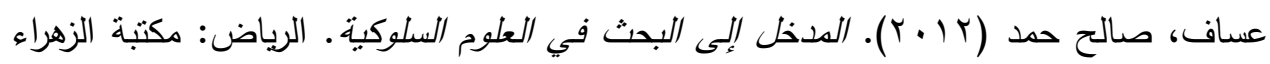
للنشر والنوزيع. 


$$
\text { عدد يناير-ج }
$$

أداء الباحثين في إعداد مشروعاتهم البحثية ....

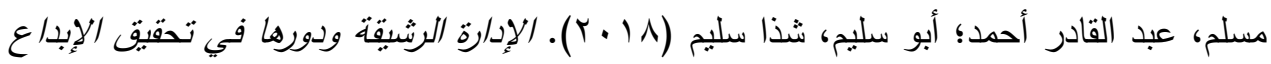

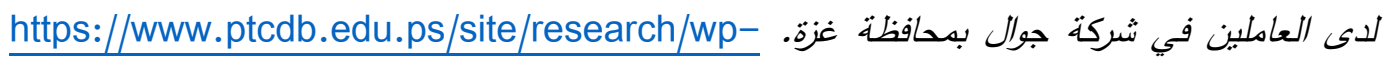
. content/uploads/sites/13/2018 ثانياً: المراجع الأجنبية: المانية

Agarwal, S., Shankar, R. \& Tiwari, M. (2007). Modeling agility of supply chain. Industrial Marketing Management, 36(4), 443- 457.

Allan, AJ \& Randy, LJ. (2005). Writing the winning thesis or dissertation. A Step-by-step guide. Corwin Press, California.

Colomb, G. G., \& Joseph M. W. (1985). Perceiving structure in professional prose: a multiply determined experience. In Writing in NonAcademic Settings, eds. Lee Odell and Dixie Goswami. Guilford Press, pp. 87128.

Creswell, J \& Creswell, J. (2018). Research design: Qualitative, quantitative and mixed approaches. $5^{\text {th }}$ ed. Unite Kingdom: Sage Publication Inc.

Creswell, J. W. (2013). Qualitative inquiry and research design: Choosing among 5 traditions. San Francisco, CA: Sage Publications.

Creswell, J. W. (2015). 30 essential skills for the qualitative researcher. Thousand Oaks, CA: Sage.

Creswell, J. W., \& Plano Clark, V. L. (2018). Designing and conducting mixed methods research (3rd ed.) Thousand Oaks, CA: Sage.

Goldman, S. L., Nagel, R. N. \& Priess, K. (1995). Agile competitors and virtual organizations: Strategies for enriching the customer. New York: Van Nostrand Reinhold.

Gopen, S.\& Swan, J. (2018). The Science of Scientific Writing. American Scientists.

Harris H.\& Carapiet S. (2006). The Need for agility in asset management. In: Mathew J., Kennedy J., Ma L., Tan A., Anderson D. (eds) Engineering Asset Management. Springer, London. https://doi.org/10.1007/978-1-84628-814-2_11.

Sheppard, J. M. \& Young, W. B. (2006) Agility literature review: Classifications, training and testing, Journal of Sports Sciences, 24:9, 919932, DOI: $\underline{10.1080 / 02640410500457109}$ 